\title{
Winter tourism under climate change in the Pyrenees and the French Alps: relevance of snowmaking as a technical adaptation
}

\author{
Pierre Spandre $^{1,2}$, Hugues François ${ }^{1}$, Deborah Verfaillie ${ }^{2,3}$, Marc Pons $^{4}$, Matthieu Vernay ${ }^{2}$, Matthieu Lafaysse $^{2}$, \\ Emmanuelle George ${ }^{1}$, and Samuel Morin ${ }^{2}$ \\ ${ }^{1}$ Univ. Grenoble Alpes, Irstea, UR LESSEM, Grenoble, France \\ ${ }^{2}$ Univ. Grenoble Alpes, Université de Toulouse, Météo-France, CNRS, CNRM, \\ Centre d'Études de la Neige, 38000 Grenoble, France \\ ${ }^{3}$ Barcelona Supercomputing Center, Barcelona, Spain \\ ${ }^{4}$ Snow and Mountain Research Center of Andorra, IEA, Sant Julià de Lòria, Andorra
}

Correspondence: Samuel Morin (samuel.morin@meteo.fr)

Received: 18 November 2018 - Discussion started: 20 December 2018

Revised: 19 March 2019 - Accepted: 2 April 2019 - Published: 24 April 2019

\begin{abstract}
Climate change is increasingly regarded as a threat for winter tourism due to the combined effect of decreasing natural snow amounts and decreasing suitable periods for snowmaking. The present work investigated the snow reliability of 175 ski resorts in France (Alps and Pyrenees), Spain and Andorra under past and future conditions using stateof-the-art snowpack modelling and climate projections using Representative Concentration Pathways RCP2.6, RCP4.5 and RCP8.5. The natural snow reliability (i.e. without snowmaking) elevation showed a significant spatial variability in the reference period (1986-2005) and was shown to be highly impacted by the ongoing climate change. The reliability elevation using snowmaking is projected to rise by 200 to $300 \mathrm{~m}$ in the Alps and by 400 to $600 \mathrm{~m}$ in the Pyrenees in the near future (2030-2050) compared to the reference period for all climate scenarios. While $99 \%$ of ski lift infrastructures exhibit adequate snow reliability in the reference period when using snowmaking, a significant fraction ( $14 \%$ to $25 \%$ ) may be considered in a critical situation in the near future. Beyond the mid-century, climate projections highly depend on the scenario with either steady conditions compared to the near future (RCP2.6) or continuous decrease in snow reliability (RCP8.5). Under RCP8.5, our projections show that there would no longer be any snow-reliable ski resorts based on natural snow conditions in the French Alps and Pyrenees (France, Spain and Andorra) at the end of the century (2080-2100). For this time period and this scenario,
\end{abstract}

only 24 resorts are projected to remain reliable with snowmaking, all being located in the Alps.

\section{Introduction}

The ongoing evolution of natural snow conditions related to climate change (Beniston et al., 2018) is increasingly regarded as a major threat for winter tourism (GilaberteBurdalo et al., 2014; Steiger et al., 2017; Hoegh-Guldberg et al., 2019). This prompts the question of how climate change affects ski resorts and the relevance of snowmaking as an adaptation measure (Steiger et al., 2017). Initial studies in the early 2000s quantified the snow reliability of ski resorts based on the " 100 days" rule, later considered as the reference approach for investigations of climate-induced impacts on the winter tourism (Koenig and Abegg, 1997; Elsasser and Bürki, 2002; Abegg et al., 2007; Steiger, 2010; Pons-Pons et al., 2012; François et al., 2014). This rule states that a ski resort is snow reliable if the snow depth exceeds $30 \mathrm{~cm}$ during $100 \mathrm{~d}$ or more, which provides objective information when comparing distinct periods (past and future) or locations (Koenig and Abegg, 1997; Elsasser and Bürki, 2002; Abegg et al., 2007; Durand et al., 2009b). The snow reliability line is defined as the elevation above which these conditions are met, allowing the assessment of the reliability of a ski resort by comparing its elevation to the snow reliabil- 
ity line (Koenig and Abegg, 1997; Elsasser and Bürki, 2002; Abegg et al., 2007; Gilaberte-Búrdalo et al., 2017).

Most investigations based on the 100 days rule used single-point representations of ski slopes to assess the snow and meteorological conditions of a given ski resort, often using the median elevation of a ski resort defined as the average of summit and base elevations (Abegg et al., 2007; Scott et al., 2003; Steiger, 2010; Dawson and Scott, 2013; Pons et al., 2015; Gilaberte-Búrdalo et al., 2017). Schmidt et al. (2012) and Rixen et al. (2011) used the "highest", "middle" and "lowest" elevations of the study area while Hennessy et al. (2007) mixed various approaches by considering either a single point or three distinct elevations for each ski resort. Alternatively, Pons-Pons et al. (2012) considered the lowest and highest elevations, between which $75 \%$ of the ski slope surface area was concentrated. These remain coarse representations limiting the analysis of the situation of a ski resort to a binary conclusion of reliable or unreliable (Steiger et al., 2017). Koenig and Abegg (1997) and Elsasser and Bürki (2002) in Switzerland and later Abegg et al. (2007) in the rest of the European Alps based their analysis on the natural snow conditions. Abegg et al. (2007) reviewed the existing literature to address the snow reliability line for regions of Europe (Austria, Italy, Germany, Switzerland and France) based on distinct methods and reference periods (Laternser and Schneebeli, 2003; Wielke et al., 2004; Matulla et al., 2005). They concluded that $91 \%$ of the 666 ski resorts in the European Alps were snow reliable around 2005. Significant spatial variations in the snow reliability line were shown, ranging from 1050 to $1500 \mathrm{~m}$ above sea level (a.s.l.) with consequences on local reliability of ski resorts: $69 \%$ of ski resorts were snow reliable in Germany and up to $97 \%$ were snow reliable in Switzerland and France. Abegg et al. (2007) similarly addressed the impact of climate change on the snow reliability line and concluded that under a $+1{ }^{\circ} \mathrm{C}$ warming compared to present only $75 \%$ of European Alps ski resorts would remain reliable and respectively $61 \%$ and $30 \%$ for +2 and $+4{ }^{\circ} \mathrm{C}$ warming compared to the present would remain reliable. These investigations were limited to the analysis of natural snow using average conditions over large regions. Steiger (2010) later showed by the analysis of 52 climate stations in Austria over the 1981-2001 period that an elevation of $1200 \mathrm{~m}$ a.s.l. could not be confirmed as snow reliable for all regions of Tyrol (Austria). Using natural snow conditions to assess the snow reliability of ski resorts has also been questioned, due to the strong role of snow management, in particular grooming and snowmaking (Hanzer et al., 2014; Spandre et al., 2016b; Steiger et al., 2017).

Recent studies have increasingly taken into account snow grooming and snowmaking (Scott et al., 2003, 2006; Steiger, 2010; Pons et al., 2015; Steiger et al., 2017). Scott et al. (2003) developed a simple modelling approach accounting for a required snow depth of $50 \mathrm{~cm}$ for skiing activities and computed snowmaking requirements based on this target. This method provided consistent season durations for the
1961-1990 reference period in the southern Ontario region (Canada) which were shown to significantly decrease under projected climate conditions despite an increasing need for snowmaking. Scott et al. (2006) later used this modelling approach and a $60 \mathrm{~cm}$ snow base depth requirement in the Quebec region (Canada). Steiger and Mayer (2008) applied this method in Tyrol (Austria) and concluded that snowmaking could guarantee snow reliability at elevations above $1000 \mathrm{~m}$ a.s.l. for the 1971-2000 reference period and would remain a suitable adaptation method until the 2050s with a significant increase in water and energy requirements (Steiger, 2010). Similar investigations were conducted to assess the impact of climate change on the ski season duration and the snowmaking requirements so as to compensate for the loss in regions of Austria (Marke et al., 2014; Hanzer et al., 2014), Germany (Schmidt et al., 2012), Switzerland (Rixen et al., 2011), Andorra (Pons-Pons et al., 2012), the Pyrenees (Pons et al., 2015; Gilaberte-Búrdalo et al., 2017), the northeastern US (Dawson and Scott, 2013), New Zealand (Hendrikx and Hreinsson, 2012) and Australia (Hennessy et al., 2007). Major limitations remain. First, little investigation was undertaken in France, still a major area for winter tourism (François et al., 2014; Steiger et al., 2017). Second, meteorological and snow input data considered for the analysis were aggregated over large regions (Abegg et al., 2007; Damm et al., 2017) where high spatial variability can be observed (Durand et al., 2009b; François et al., 2014). Third, snow conditions were often simulated using simplified degree day modelling approaches (Dawson and Scott, 2013; Hendrikx and Hreinsson, 2012) and neglected the differences between natural snow and groomed or machine-made snow properties (Pons et al., 2015; Gilaberte-Búrdalo et al., 2017).

The present work aims at producing snow reliability investigations of a wide range of ski resorts in France (Alps and Pyrenees), Spain and Andorra under past and future conditions using state-of-the-art snowpack modelling. We accounted for snow grooming and snowmaking using a detailed snowpack model (Spandre et al., 2016b) and used adjusted and downscaled climate projections from the EUROCORDEX dataset (Verfaillie et al., 2017, 2018) to compute snow reliability elevations with distinct levels of snow reliability requirements. The mean elevation of residential population in a ski resort (Breiling and Charamza, 1999) and the mean elevation of ski lifts (Falk and Vanat, 2016) were compared to the snow reliability line. We defined seven distinct categories for ski resorts based on their natural snow reliability, their degree of dependence on snowmaking to achieve reliability (Pons et al., 2015) and whether snowmaking may be a technically efficient method to guarantee snow reliability under present and future climate conditions. 


\section{Method}

\subsection{Ski resort definition and features}

\subsubsection{Definition of relevant elevations of ski resorts}

All data on the geographical location and technical data on ski resorts were extracted from the "BD Stations" database (François et al., 2014; Spandre et al., 2015). Ski lift installation and operation in France are supervised by the STRMTG ("Services Techniques de Remontées Mécaniques et Transports Guidés"). The STRMTG is a public service in charge of the safety control of French ski lifts providing authorizations for ski lift operations. The STRMTG manages a database (CAIRN: CAtalogue Informatisé des Remontées Mécaniques Nationales) dedicated to ski lifts which includes technical characteristics of each ski lift such as the ski lift power. The ski lift power is an indicator of the size of a ski lift, defined as the product of the elevation difference between the bottom and the top of a ski lift (in kilometres) and its capacity, i.e. the flow of persons per hour (persons $\mathrm{h}^{-1}$ ), expressed in persons $\mathrm{km} \mathrm{h}^{-1}$. Ski lift infrastructures in France have a total ski lift power of 977000 persons $\mathrm{km} \mathrm{h}^{-1}, 94 \%$ of which are included in the present study (Appendix B). These data are complemented with geographical information from the database BD TOPO ( $25 \mathrm{~m}$ of resolution) developed by the French Geographical Institute (IGN, "Institut Géographique National"). The following elevations were used to be compared with the snow reliability line.

- The mean ski lift elevation of a ski resort is defined as the average of top and bottom elevations of each ski lift weighted by its ski lift power, referred to as the mean elevation of the ski resort (François et al., 2014; Falk and Vanat, 2016).

- The village elevation of a ski resort is defined as the mean elevation of tourism housing infrastructure, where tourists stay during their ski holidays. It is computed using IGN data on the location and characteristics of buildings. Buildings located within $300 \mathrm{~m}$ from the bottom of the ski lifts are selected, and the selection procedure continues by iterations, using a $200 \mathrm{~m}$ radius around each identified building and so on, until no more buildings are found. We then compute the net floor surface area of each selected building (taking account the number of floors, based on building height), which is used to compute the weighted mean elevation of the built area associated with each resort, weighted by their net floor area (Breiling and Charamza, 1999).

Data for computing the mean ski lift elevation and village elevation of ski resorts using the method described above are only available for France. Another approach was required for addressing the characteristics of ski resorts in Andorra and
Spain. Based on the OpenStreetMap (OSM) project (http: //www.openstreetmap.org/, last access: 12 April 2019), we estimated the main features for the Spanish and Andorran ski resorts (village elevation, ski lift mean elevation and ski lift power). However, ski lift capacity is not included in OSM, and building height data are incomplete, which hampers our ability to proceed using the method developed for the French ski resorts. To circumvent this issue, we extracted all ski slopes from OSM for all ski resorts in France, Spain and Andorra, and computed linear regressions between information extracted from OSM and independent estimates for French ski resorts, which were then used to compute the indicators for ski resorts in Spain and Andorra (Fig. 1).

- The linear model of the ski lift power versus the OSM surface area (Fig. 1a) had a correlation coefficient $R^{2}=$ 0.87 ( $p$ value $<10^{-15}$ ), proving relevant to estimate the ski lift power based on the OSM surface area.

- Elevations derived from the OSM spatial representation also proved significantly correlated to data from the BD Stations (Fig. 1b):

- All elevations together had a RMSD $=149 \mathrm{~m}$ and mean difference $=15 \mathrm{~m}$, and the linear model of slope was $0.97\left(R^{2}=0.91, p\right.$ value $\left.<10^{-15}\right)$.

- Mean elevation had a RMSD $=154 \mathrm{~m}$ and mean difference $=51 \mathrm{~m}$, and the linear model of slope was $0.82\left(R^{2}=0.83, p\right.$ value $\left.<10^{-15}\right)$.

- The village elevation proved significantly correlated to the mean elevation derived from OSM spatial representations (slope 0.64, intercept $326 \mathrm{~m}$, $R^{2}=0.62, p$ value $<10^{-15}$ ). The linear model was applied to estimate the village elevation from the OSM mean elevation and compared to the BD Stations data: $\mathrm{RMSD}=179 \mathrm{~m}$; mean difference $<$ $10^{-12}$ (Fig. 1b).

\subsubsection{Study area}

A sample of 175 ski resorts in the French Alps $(n=129)$, the French Pyrenees $(n=28)$, the Spanish Pyrenees $(n=14)$ and Andorra $(n=4)$ were included in the present study (Fig. 2, Appendix B). The French ski resorts included in this study $(n=157)$ represent $94 \%$ of the national ski lift infrastructures. For Andorra, our study accounts for $100 \%$ of the ski tourism infrastructures. For Spain, there are a total of $30 \mathrm{ski}$ resorts, 14 of which are in the Spanish Pyrenees and considered in this study (note that in our study, the ski resorts La Molina and Masella were considered together). In terms of skiers, the Spanish Pyrenees represent around $63 \%$ of the total ski market in Spain. 

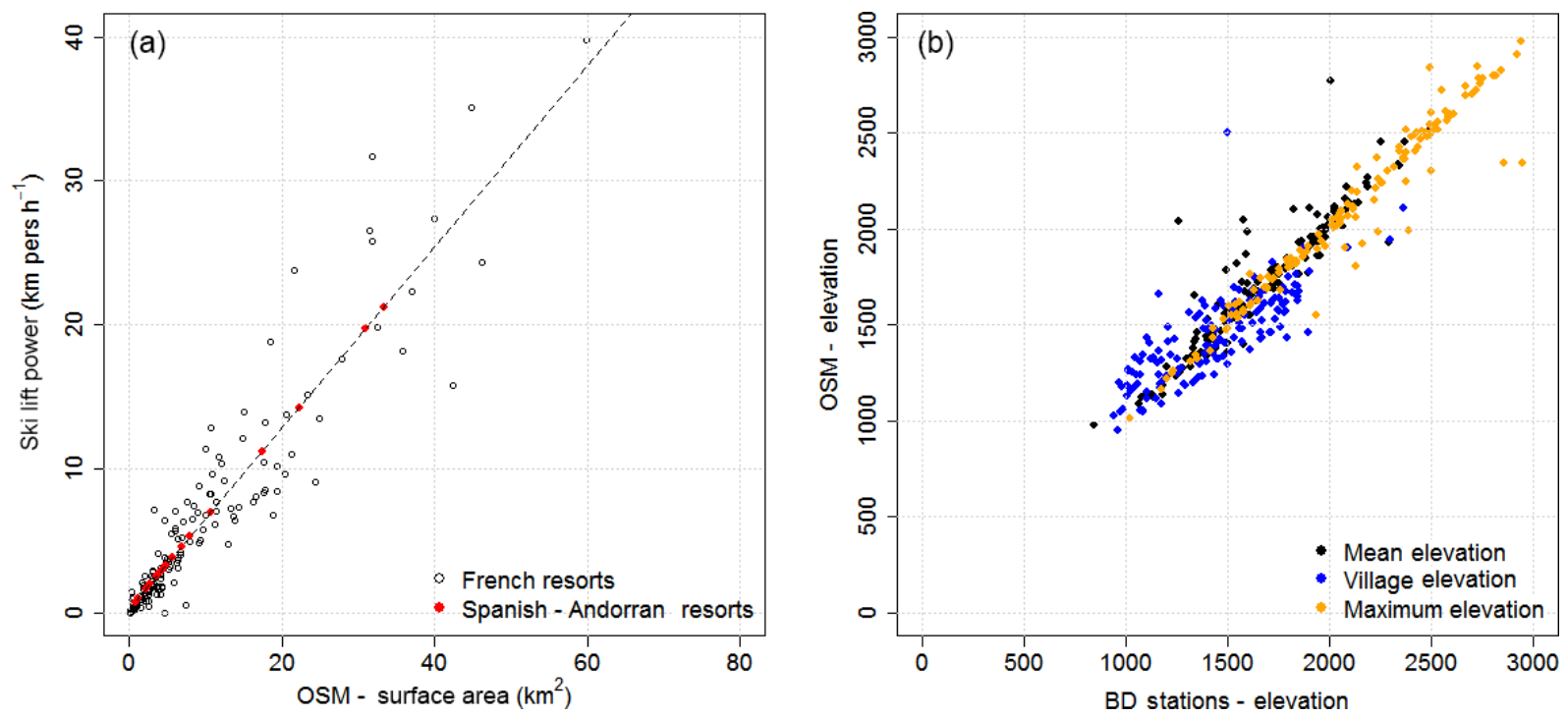

Figure 1. Relationship between OpenStreetMap (OSM) data on French ski resorts and ski lift power (SLP) and elevations of the ski resort (min, mean, max), used to estimate similar indicators in ski resorts in Spain and Andorra. In panel (b), "BD Stations" refers to the database of French ski resorts used in this study (see text for details).
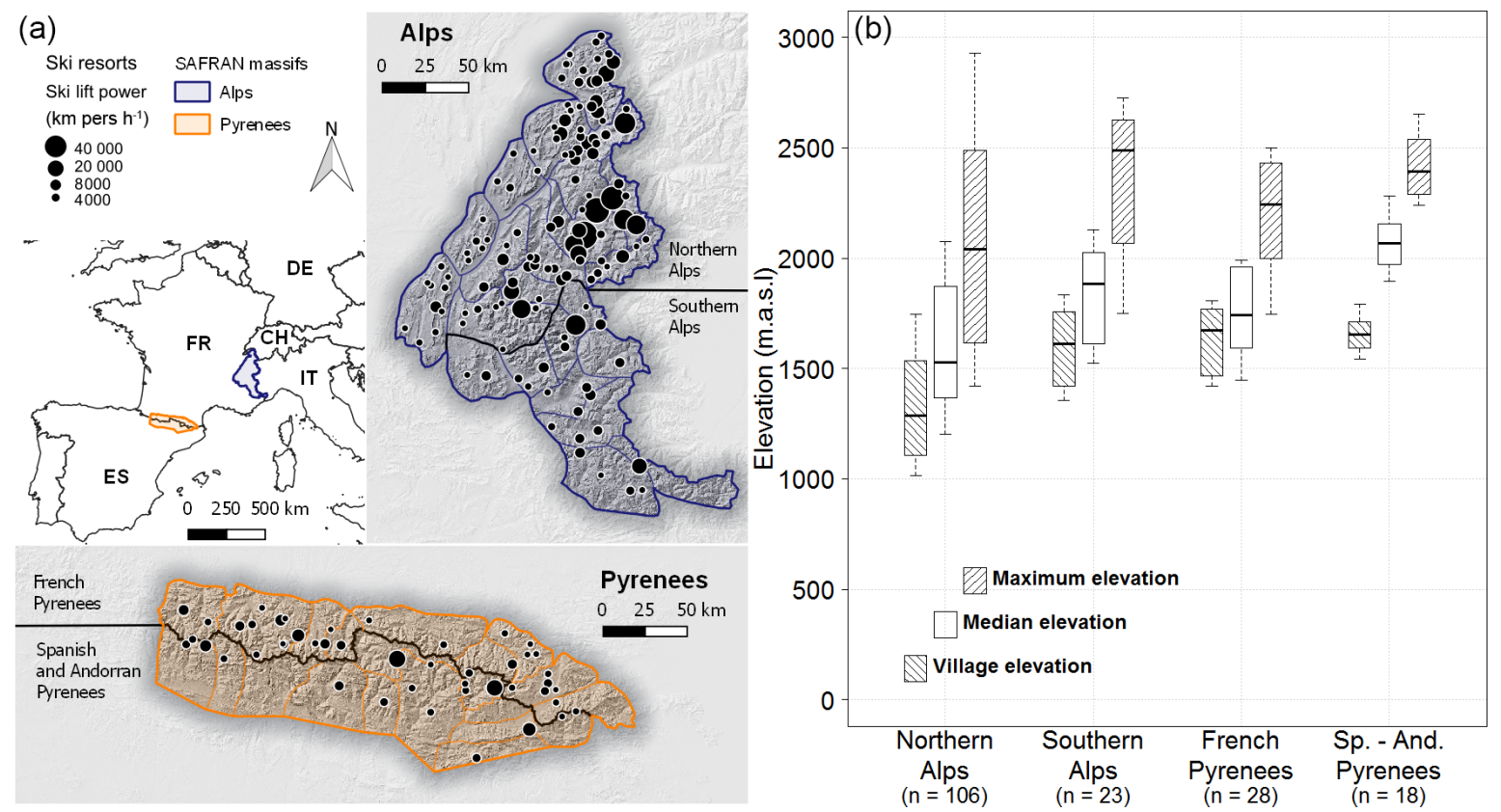

Figure 2. (a) The 175 ski resorts covered by the present study and the 44 massifs from the SAFRAN reanalysis and (b) distribution of ski resort elevations depending on their location: northern Alps, southern Alps, French Pyrenees, and Spanish and Andorran Pyrenees ("Sp.-And. Pyrenees"). See Appendix B.

\subsection{Definition and computation of the snow reliability line}

\subsubsection{Snowpack modelling}

The "Crocus Resort" version of the multilayer snowpack model SURFEX/ISBA-Crocus was used in the present study
(Brun et al., 1992; Vionnet et al., 2012). Crocus Resort allows us to take into account the effect of grooming and snowmaking on snow properties so as to provide simulations of snow conditions on ski slopes (Spandre et al., 2016b). The impacts of grooming are simulated and machine-made snow can be added to the snowpack specifying the precipitation rate $\left(1.2 \times 10^{-3} \mathrm{~kg} \mathrm{~m}^{-2} \mathrm{~s}^{-1}\right.$; Spandre et al., 2016a) and con- 
ditions for triggering the production (wet-bulb temperature threshold $-2{ }^{\circ} \mathrm{C}$, target quantity or target snow depth). The production of snow was based on the following rules, dividing the winter season into distinct periods (Steiger, 2010; Hanzer et al., 2014; Spandre et al., 2016a):

- Between 1 November and 15 December, a $30 \mathrm{~cm}$ deep "base layer" (snow mass of $150 \mathrm{~kg} \mathrm{~m}^{-2}$, for a typical snow density of $500 \mathrm{~kg} \mathrm{~m}^{-3}$ ) is produced, weather conditions permitting, regardless of natural snowfalls during the period.

- Between 15 December and 28 February, snow is produced, if meteorologically possible, so as to maintain a total snow depth of $60 \mathrm{~cm}$.

- After 1 March, no more snow is produced.

\subsubsection{Climate forcing data}

The meteorological system SAFRAN (Durand et al., 1993) provides meteorological data (temperature, precipitations, etc.) for mountain areas of an approximate $1000 \mathrm{~km}^{2}$ surface referred to as a "massif", covering the French Alps and Pyrenees, including the Spanish and Andorran Pyrenees (Fig. 2). Within each massif, the meteorological conditions are considered to be homogeneous and to depend only on the elevation (by steps of $300 \mathrm{~m}$ ) with a time resolution of $1 \mathrm{~h}$. SAFRAN forcing data are available for the 1958-2015 period (Durand et al., 2009a; Durand et al., 2012; Maris et al., 2009). Computations of snow conditions over the reference period using SAFRAN forcing data are further referred to as "SAFRAN" and can be considered as the reference observational dataset.

This study uses the EURO-CORDEX dataset (Jacob et al., 2014; Kotlarski et al., 2014) for climate projections consisting of six regional climate models (RCMs) forced by five different global climate models (GCMs) from the CMIP5 ensemble (Taylor et al., 2012) over Europe, for the historical, RCP2.6, RCP4.5 and RCP8.5 scenarios (Moss et al., 2010). All EURO-CORDEX data were adjusted using the ADAMONT method (Verfaillie et al., 2017) using the SAFRAN data as the reference observation dataset (Verfaillie et al., 2018). Historical runs generally cover the period 1950-2005 and climate projections (RCPs) cover the period 2006-2100 (Table 1). Continuous hourly resolution meteorological time series derived from RCM output by the ADAMONT statistical adjustment method are then used as input of the SURFEX/ISBA-Crocus snowpack model (Verfaillie et al., 2017, 2018).

\subsubsection{Snow indicators}

The snow reliability line was computed from the simulated snow conditions for the reanalysis and all GCM-RCM pairs and scenarios. The snow reliability line was based on the 100 days rule and defined for a given season as the elevation above which a minimum quantity of $100 \mathrm{~kg} \mathrm{~m}^{-2}$ of snow (i.e. $20 \mathrm{~cm}$ of snow at $500 \mathrm{~kg} \mathrm{~m}^{-3}$ density) was simulated during at least $100 \mathrm{~d}$ between 15 December and 15 April (Scott et al., 2003; Steiger, 2010; Marke et al., 2014; Pons et al., 2015). The use of snow mass instead of snow depth (Marke et al., 2014) appeared more relevant for our study, considering the differences between natural snow properties and machinemade snow or groomed snow (Spandre et al., 2016b). Based on the season length computed for SAFRAN massif elevations (300 $\mathrm{m}$ step), a linear interpolation was used to compute the snow reliability line meeting the $100 \mathrm{~d}$ threshold. In cases where the season length at the minimum (respectively maximum) elevation was longer (respectively shorter) than $100 \mathrm{~d}$, the snow reliability line was set to half the altitudinal step $(150 \mathrm{~m})$ below (respectively above) the minimum (respectively maximum) elevation for a given massif. We further computed for each massif the snow reliability line by considering distinct periods, climate scenarios, snow requirements and snow management, providing 48 distinct values of the snow reliability elevation resulting from the combination of these parameters (Tables A1, A2, A3 in Appendix). Eight periods and scenario configurations are based on the reference period (1986-2005) using the SAFRAN reanalysis and available GCM-RCM pairs (HIST), the near future (2030-2050) and the end of the century (2080-2100), using climate scenarios RCP2.6, RCP4.5 and RCP8.5 for all available GCM-RCM pairs (Table 1). Three distinct levels of snow reliability requirements were defined as the elevation where the season length reached $100 \mathrm{~d}$ one season out of two (50\% percentile of annual values), seven seasons out of 10 (70\% percentile of annual values) and nine seasons out of 10 (90\% percentile of annual values). Last, we considered the groomed snow conditions (no snowmaking) and including snowmaking (two configurations). We did not compute indicators based on unmanaged natural snow conditions alone, i.e. without grooming or snowmaking.

\subsection{Definition of snow reliability categories}

Seven snow reliability categories have been designed with respect to the natural snow reliability and the relevance of snowmaking as an efficient adaptation method to reduce the effect of snow variability and scarcity, in line with previous investigations (Pons et al., 2015; Steiger and Mayer, 2008). Following Steiger and Mayer (2008), we considered a strict threshold of nine winters out of 10 for snowmaking reliability (90\% percentile of annual values), considering that snowmaking facilities are an investment for the operations of ski resorts and should therefore target a high level of reliability. The following categories were defined to characterize the snow reliability of ski resorts, depending on the relationship between village elevation and mean ski lift elevation, and the reliability lines with and without snowmaking. The village elevation is critical because this corresponds to the entry point of skiers to the ski slopes from their tourism housing in- 
Table 1. EURO-CORDEX GCM-RCM combinations used in this study (rows: RCMs; columns: GCMs), with the time period available for the HIST and RCP4.5 and RCP8.5 scenarios (RCPs). Model combinations additionally using RCP2.6 are displayed in bold. Contributing institutes are indicated inside parentheses - CLMcom: Climate Limited-area Modelling Community with contributions by BTU, DWD, ETHZ, UCD,WEGC; CNRM: Météo France; IPSL-INERIS: Institut Pierre Simon Laplace, CNRS, France - Laboratoire des Sciences du Climat et de l'Environnement, IPSL, CEA/CNRS/UVSQ - Institut National de l'Environnement Industriel et des Risques, Verneuil en Halatte, France; KNMI: Kingdom of Netherlands Meteorological Institute, Ministry of Infrastructure and the Environment; MPI-CSC: Max Planck Institute for Meteorology, Climate Service Center, Hamburg, Germany; SMHI: Swedish Meteorological and Hydrological Institute, Rossby Centre, Norrköping, Sweden.

\begin{tabular}{|c|c|c|c|c|c|c|}
\hline RCM (institute)-GCM & Period & CNRM-CM5 & EC-EARTH & HadGEM2-ES & MPI-ESM-LR & IPSL-CM5A-MR \\
\hline \multirow[t]{2}{*}{ CCLM 4.8.17 (CLMcom) } & HIST & 1950-2005 & 1950-2005 & $1981-2005$ & 1950-2005 & \\
\hline & RCPs & $2006-2100$ & $2006-2100$ & 2006-2099 & $2006-2100$ & \\
\hline \multirow[t]{2}{*}{ ALADIN 53 (CNRM) } & HIST & 1950-2005 & & & & \\
\hline & RCPs & 2006-2100 & & & & \\
\hline \multirow[t]{2}{*}{ WRF 3.3.1F (IPSL-INERIS) } & HIST & & & & & $1951-2005$ \\
\hline & RCPs & & & & & $2006-2100$ \\
\hline \multirow[t]{2}{*}{ RACMO 2.2E (KNMI) } & HIST & & & $1981-2005$ & & \\
\hline & RCPs & & & 2006-2099 & & \\
\hline \multirow[t]{2}{*}{ REMO 2009 (MPI-CSC) } & HIST & & & & 1950-2005 & \\
\hline & RCPs & & & & 2006-2100 & \\
\hline \multirow[t]{2}{*}{ RCA 4 (SMHI) } & HIST & 1970-2005 & 1970-2005 & $1981-2005$ & 1970-2005 & 1970-2005 \\
\hline & RCPs & $2006-2100$ & 2006-2100 & 2006-2099 & 2006-2100 & $2006-2100$ \\
\hline
\end{tabular}

frastructure. This often corresponds to the lower elevation of the major ski lift infrastructure, which is a key area for snow managers because snow reliability there is both challenging and a strong asset for the ski resort operations (Spandre et al., 2016a). Categories are ordered by decreasing levels of natural and managed snow reliability. For each ski resort, its category corresponds to the first one for which the criterion is fulfilled, from category 1 until category 7 . A ski resort fulfilling the condition of category $\mathrm{N}-1$ also fulfills the condition of category N. Ski resorts in category $\mathrm{N}$ fulfill the condition of category $\mathrm{N}$ but not the condition of category $\mathrm{N}-1$.

- Category 1: village elevation above the $90 \%$ groomed snow reliability line.

- Category 2: village elevation above the $70 \%$ groomed snow reliability line and village elevation above the $90 \%$ snowmaking reliability line.

- Category 3: mean ski lift elevation above the $70 \%$ groomed snow reliability line and village elevation above the $90 \%$ snowmaking reliability line.

- Category 4: mean ski lift elevation above the $50 \%$ groomed snow reliability line and village elevation above the $90 \%$ snowmaking reliability line.

- Category 5: village elevation above the $90 \%$ snowmaking reliability line.

- Category 6: mean ski lift elevation above the $90 \%$ snowmaking reliability line.
- Category 7: mean ski lift elevation below the $90 \%$ snowmaking reliability line.

Categories 1, 2 and 3 illustrate ski resorts where natural snow conditions are generally reliable (Abegg et al., 2007; Scott et al., 2003; Pons et al., 2015). Snowmaking is generally employed only at the lowest elevations, and it makes a difference only for a minority of seasons when natural snow conditions are too scarce. Categories 4 and 5 illustrate ski resorts where natural snow conditions may not be considered as reliable as the previous categories, but snowmaking can generally guarantee the reliability in all elevations of the resort. In these two categories, snowmaking is useful and efficient in reducing natural snow scarcity at all elevations of the resort (Pons et al., 2015). Categories 6 and 7 illustrate ski resorts where natural snow conditions are generally not considered reliable and snowmaking is not efficient in reducing natural snow scarcity at the lowest elevations of the resort.

\section{Results}

\subsection{Snow conditions and snow reliability line}

\subsubsection{Past climate conditions}

Figure 3 shows that a significant spatial variability of the snow reliability line can be observed for the reference period (1986-2005). The median elevation of the $70 \%$ groomed snow reliability ranges between $1750 \mathrm{~m}$ a.s.l. in the northern 


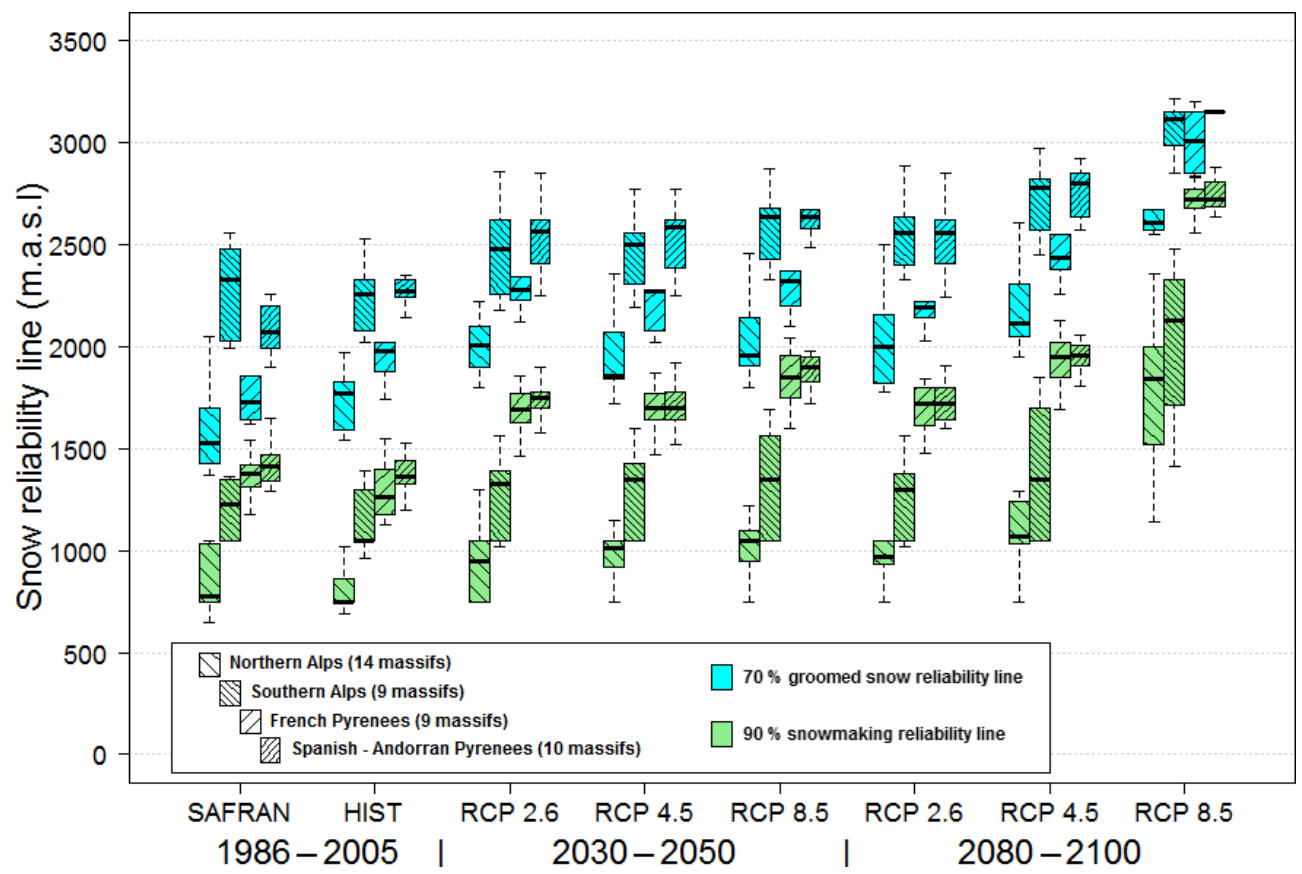

Figure 3. Spatial variability between massifs and evolution for the reference period, the near future (2030-2050) and the end of the century (2080-2100) of the snow reliability line based on RCP2.6, RCP4.5 and RCP8.5 for the main areas covered in the present study (northern and southern Alps, French and Spanish-Andorran Pyrenees).

Alps, $2000 \mathrm{~m}$ a.s.l. in the French Pyrenees, $2250 \mathrm{~m}$ a.s.l. in the southern Alps, and up to 2300 m a.s.l. in the Spanish and Andorran Pyrenees (HIST, Fig. 3). Although a deviation can be observed, the spatial variability is consistent between climate model computations over the reference period (HIST) and the reference dataset (SAFRAN). The $90 \%$ snow reliability using snowmaking is significantly lower than the $70 \%$ groomed snow reliability line (Fig. 3). Due to snowmaking the median reliability elevation increases between $700 \mathrm{~m}$ in the French Pyrenees, $900 \mathrm{~m}$ in the Spanish and Andorran Pyrenees, $1000 \mathrm{~m}$ in the northern Alps, and up to $1200 \mathrm{~m}$ in the southern Alps. This results in a snowmaking reliability line significantly lower in the southern Alps compared to the Pyrenees despite poorer natural snow conditions (Fig. 3). Although the improvement of snow conditions thanks to snowmaking is lower in the Pyrenees compared to the Alps, the annual snowmaking requirements are higher, with 400 to $550 \mathrm{~kg} \mathrm{~m}^{-2}$ machine-made snow produced at the snow reliability line in the northern and southern Alps (10\%-90\% percentiles of annual values) and 400 to $700 \mathrm{~kg} \mathrm{~m}^{-2}$ in the French, Spanish and Andorran Pyrenees (HIST). Such production is equivalent to $80 \mathrm{~cm}$ to $1.1 \mathrm{~m}$ of snow in the Alps and $80 \mathrm{~cm}$ to $1.4 \mathrm{~m}$ of snow in the Pyrenees at the snow reliability line (using a machine-made snow density value of $500 \mathrm{~kg} \mathrm{~m}^{-3}$ ).

\subsubsection{Future change in the near future (2030-2050)}

Natural snow conditions are projected to be significantly affected by climate change in the near future (2030-2050) with similar evolution between climate scenarios (Fig. 3). The median $70 \%$ groomed snow reliability line is projected to range between

- 1850 and 2000 ma.s.l. in the northern Alps (100 to $250 \mathrm{~m}$ above the reference period);

- 2500 and $2650 \mathrm{~m}$ a.s.l. in the southern Alps (200 to $400 \mathrm{~m}$ above the reference period);

- 2250 and $2300 \mathrm{~m}$ a.s.l. in the French Pyrenees (300 to $350 \mathrm{~m}$ above the reference period);

- 2550 and $2650 \mathrm{~m}$ a.s.l. in the Spanish and Andorran Pyrenees ( 300 to $350 \mathrm{~m}$ above the reference period).

Due to the combined effect of decreasing natural snow conditions and decreasing suitable conditions for snowmaking, the $90 \%$ snow reliability line using snowmaking is projected to rise by 200 to $300 \mathrm{~m}$ in the northern Alps, $300 \mathrm{~m}$ in the southern Alps and up to 400 to $600 \mathrm{~m}$ in the Pyrenees compared to the reference period. In the near future the median elevation of the snowmaking reliability is projected to range between 950 and $1050 \mathrm{~m}$ a.s.l. in the northern Alps, $1350 \mathrm{~m}$ a.s.l. in the southern Alps, 1700 to 1850 m a.s.l. in the French Pyrenees, and 1750 to $1900 \mathrm{~m}$ a.s.l. in the Spanish and Andorran Pyrenees. The production of machine-made snow at the snow 
reliability line is projected to remain steady or to decrease in the Pyrenees, up to $15 \%$ compared to the reference period. In the Alps, the production of machine-made snow is projected to increase for all scenarios up to $15 \%$. This highlights the higher suitability of climate conditions for snowmaking in the Alps compared to the Pyrenees and increases the gap in the elevation of the snowmaking reliability between these areas (Fig. 3).

\subsubsection{Future change at the end of the century (2080-2100)}

The impact of climate change on natural snow conditions beyond the mid-century is projected to be highly dependent on the climate scenario. Conditions at the end of the century (2080-2100) are projected to remain similar to those in the near future, for RCP2.6, with the median $70 \%$ groomed snow reliability line ranging between 200 and $300 \mathrm{~m}$ above the elevation for the reference period. Under RCP8.5, this elevation at the end of the century would be $850 \mathrm{~m}$ higher than the value for the reference period in the northern and southern Alps, $900 \mathrm{~m}$ in the Spanish and Andorran Pyrenees, and up to $1050 \mathrm{~m}$ in the French Pyrenees.

The snowmaking reliability elevation is projected to suffer from the decrease in periods suitable for snowmaking. The median elevation at the end of the century is projected to be $200 \mathrm{~m}$ (northern Alps) to $450 \mathrm{~m}$ (French Pyrenees) higher than the value for the reference period for RCP2.6 and up to $1100 \mathrm{~m}$ (northern and southern Alps) to $1450 \mathrm{~m}$ (French Pyrenees) higher for RCP8.5. The median elevation of the reliability using snowmaking for RCP8.5 is projected to range at the end of the century between $1850 \mathrm{~m}$ a.s.l. in the northern Alps, $2150 \mathrm{~m}$ a.s.l. in the southern Alps, and $2700 \mathrm{~m}$ a.s.l. in the French, Spanish and Andorran Pyrenees (Fig. 3).

In the Pyrenees, the production of machine-made snow is projected to decrease by $15 \%$ to $35 \%$ in the French Pyrenees and $10 \%$ to $20 \%$ in the Spanish and Andorran Pyrenees (10\%-90\% percentiles) compared to the reference period due to the lack of suitable conditions. In the Alps, snowmaking is projected to remain relatively steady at the snow reliability elevation compared to the near future with higher requirements compared to the reference period up to $10 \%$.

\subsection{Snow reliability of ski resorts}

\subsubsection{Past climate conditions}

Figures 3 and 4 and Table 2 show a deviation between the SAFRAN reference dataset and results derived from climate models (HIST) for the reference period. We therefore focus our analysis on the comparison of snow conditions computed by climate models for the reference and future periods. Based on climate models, ski lift infrastructures were reliable during the reference period (1986-2005), with either natural snow conditions $(50 \%$ in categories 1,2 and 3 altogether;
Table 2, HIST) or with snowmaking (49\% in categories 4 and 5 altogether). Natural snow conditions in larger ski resorts were more reliable than in the smaller ones with 44 resorts representing $50 \%$ of the ski lift power being reliable using natural snow only and 129 ski resorts also representing $49 \%$ of the ski lift power being only reliable with snowmaking (Table 2). Categories 6 and 7 include resorts where $90 \%$ snowmaking reliability can not be achieved at the elevation of the village (category 6) or at the mean ski lift elevation (category 7). These categories represent the situation of a marginal fraction of ski resorts in the reference period: less than $1 \%$ unreliable facilities (two resorts in these categories) and might therefore be considered in a critical situation in terms of snow conditions. Figures 4 and 5 also illustrate a significant geographical pattern with most naturally snowreliable ski resorts being located in the northern Alps and central Pyrenees. This can be related to the lower elevation of the snow reliability line in the northern Alps compared to the southern Alps or the Pyrenees (Fig. 3, Appendix A1) and the higher elevation of larger ski resorts, most of them being located in the northern Alps and central Pyrenees (Figs. 2 and 5). The variability is particularly high between the northern Alps (a majority of ski resorts were naturally snow reliable: $67 \%$ of ski lift power) and the southern Alps (89\% were reliable with snowmaking) highlighting a higher dependence of southern Alps ski resorts on snowmaking in the reference period (only $12 \%$ of ski lift power was naturally snow reliable). The situation of the Pyrenees ski resorts lies in between (Fig. 5).

\subsubsection{Future change in the near future $(2030-2050)$}

In the near future (2030-2050) and depending on the RCP, only 14 to 24 ski resorts ( $21 \%$ to $32 \%$ of ski lift power) are projected to remain snow reliable based on natural conditions, all being located in the northern Alps except one in the central Pyrenees (Table 2). An additional 83 to 116 resorts (representing $49 \%$ to $64 \%$ of ski lift power) are projected to remain reliable with snowmaking. Overall, a majority of ski resorts would remain reliable, either with snowmaking or under natural snow conditions ( $75 \%$ to $86 \%$ of ski lift power). A significant fraction of 45 to 75 ski resorts (14\% to $25 \%$ of ski lift power) would however turn either into category 6 ( $12 \%$ to $18 \%$ of ski lift power) or even category 7 (2\% to $7 \%$ of ski lift power) where $90 \%$ snowmaking reliability can not be achieved at the elevation of the village (category 6) or at the mean ski lift elevation (category 7). The geographical pattern identified for past climate conditions is projected to remain in the near future. Even though there would not be any naturally snow-reliable ski resort in the southern Alps, snow conditions are projected to remain reliable with snowmaking for most resorts (reduction from $100 \%$ to $89 \%$ of reliable with snowmaking ski lift power), displaying a consistent distribution between reliability categories compared to the reference period (Fig. 4). Conversely, the projected im- 

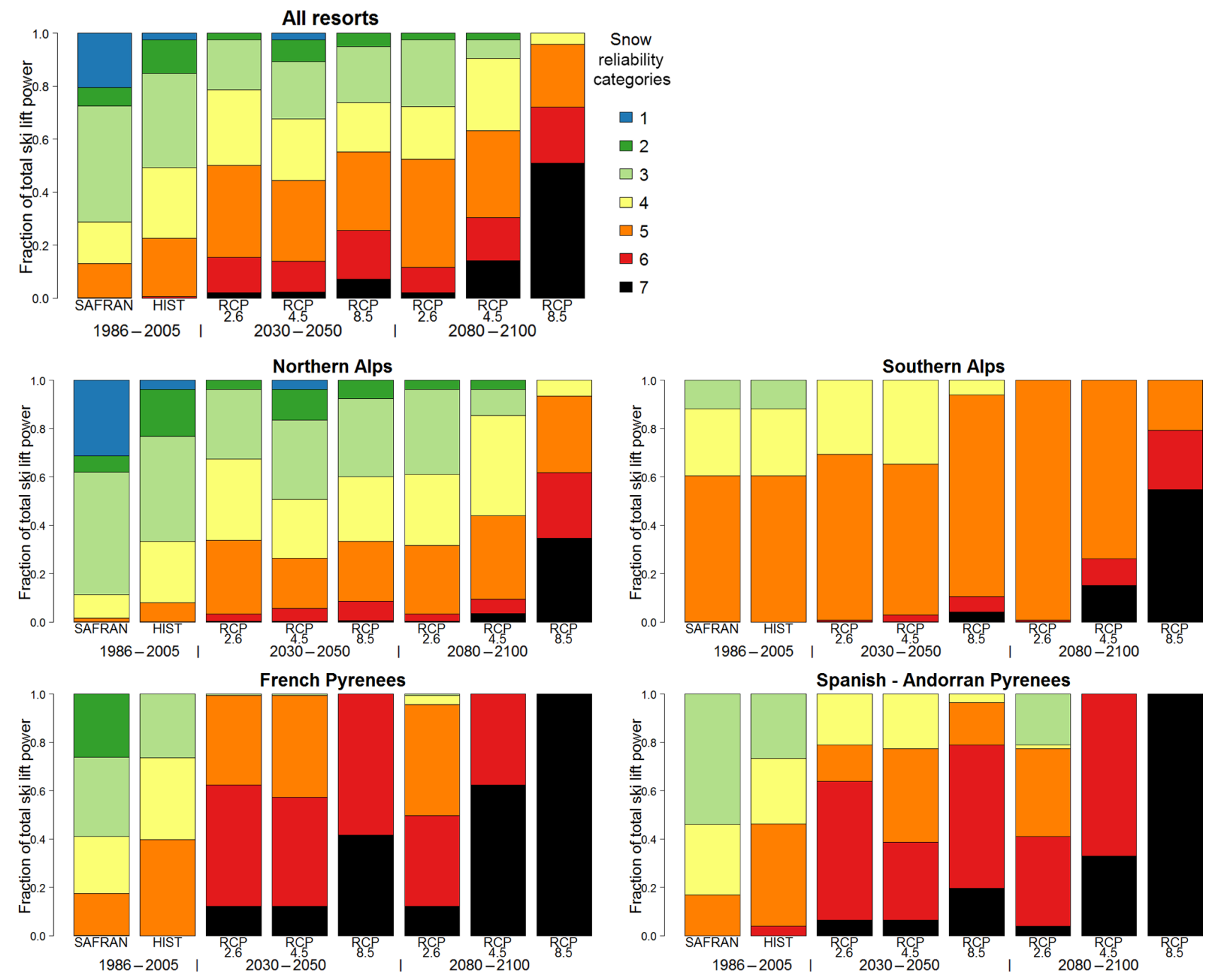

Figure 4. Distribution of the total ski lift power (\%) within reliability categories for distinct periods and scenarios (Table 2).

pact on the Pyrenees ski resorts is significant, particularly in the French Pyrenees. There would remain a single naturally snow reliable resort, but more important is the fraction of resorts turning into category 6 ( $45 \%$ to $58 \%$ of ski lift power in the French Pyrenees and $32 \%$ to $59 \%$ in the Spanish and Andorran Pyrenees) or even category 7 (12\% to $42 \%$ of ski lift power in the French Pyrenees and $7 \%$ to $20 \%$ in the Spanish and Andorran Pyrenees).

\subsubsection{Future change at the end of the century (2080-2100)}

Beyond the near future, the evolution of snow conditions strongly depends on the climate scenario, due to both the evolution of natural snow conditions and the availability of suitable periods for snowmaking (Fig. 3). According to the scenario RCP2.6, snow reliability is projected to remain similar or even improve at the end of the century (2080-2100) compared to the near future (2030-2050). Figures 3 and 4 and Table 2 illustrate the significant impact of climate change on the snow conditions and ski resort reliability for RCP8.5 compared to the two other scenarios. Our projections indicate that there would not remain any ski resort with reliable natural snow conditions based on RCP8.5, with only 24 ski resorts ( $28 \%$ of ski lift power) benefiting from snowmaking reliability (Table 2), all of them being located in the Alps. Figure 4 illustrates a strong geographical pattern within the Alps with higher snow reliability in eastern central Alps compared to external and southern massifs. End of century RCP8.5 ski resorts reliable with snowmaking are projected to be located in Vanoise $(n=7)$, Haute-Tarentaise $(n=5)$, Maurienne $(n=5)$ and Haute-Maurienne $(n=3)$ in the northern Alps, and Thabor $(n=1)$, Pelvoux $(n=1)$, Queyras $(n=1)$ and Champsaur $(n=1)$ in the southern Alps. 
Table 2. Distribution of the total ski lift power (\%) within reliability categories for distinct periods and scenarios (Fig. 4) with the corresponding number of ski resorts $(n)$.

\begin{tabular}{|c|c|c|c|c|c|c|c|c|}
\hline \multirow[b]{2}{*}{ Category } & \multicolumn{2}{|c|}{$\begin{array}{c}\text { Reference } \\
(1986-2005)\end{array}$} & \multicolumn{3}{|c|}{$\begin{array}{l}\text { Near future } \\
(2030-2050)\end{array}$} & \multicolumn{3}{|c|}{$\begin{array}{l}\text { End of the century } \\
\quad(2080-2100)\end{array}$} \\
\hline & SAFRAN & HIST & RCP2.6 & RCP4.5 & RCP8.5 & RCP2.6 & $\mathrm{RCP} 4.5$ & RCP8.5 \\
\hline 1 & $\begin{array}{r}21 \\
(n=11)\end{array}$ & $\begin{array}{r}2 \\
(n=2)\end{array}$ & 0 & $\begin{array}{r}2 \\
(n=2)\end{array}$ & 0 & 0 & 0 & 0 \\
\hline 2 & $\begin{array}{r}7 \\
(n=15)\end{array}$ & $\begin{array}{r}13 \\
(n=7)\end{array}$ & $\begin{array}{r}2 \\
(n=2)\end{array}$ & $\begin{array}{r}8 \\
(n=3)\end{array}$ & $\begin{array}{r}5 \\
(n=3)\end{array}$ & $\begin{array}{r}2 \\
(n=2)\end{array}$ & $\begin{array}{r}2 \\
(n=2)\end{array}$ & 0 \\
\hline 3 & $\begin{array}{r}44 \\
(n=53)\end{array}$ & $\begin{array}{r}35 \\
(n=35)\end{array}$ & $\begin{array}{r}19 \\
(n=12)\end{array}$ & $\begin{array}{r}22 \\
(n=19)\end{array}$ & $\begin{array}{r}21 \\
(n=14)\end{array}$ & $\begin{array}{r}25 \\
(n=16)\end{array}$ & $\begin{array}{r}7 \\
(n=4)\end{array}$ & 0 \\
\hline 4 & $\begin{array}{r}16 \\
(n=42)\end{array}$ & $\begin{array}{r}27 \\
(n=51)\end{array}$ & $\begin{array}{r}29 \\
(n=25)\end{array}$ & $\begin{array}{r}23 \\
(n=24)\end{array}$ & $\begin{array}{r}19 \\
(n=19)\end{array}$ & $\begin{array}{r}20 \\
(n=23)\end{array}$ & $\begin{array}{r}27 \\
(n=20)\end{array}$ & $\begin{array}{r}4 \\
(n=2)\end{array}$ \\
\hline 5 & $\begin{array}{r}13 \\
(n=50)\end{array}$ & $\begin{array}{r}22 \\
(n=78)\end{array}$ & $\begin{array}{r}35 \\
(n=91)\end{array}$ & $\begin{array}{r}31 \\
(n=81)\end{array}$ & $\begin{array}{r}30 \\
(n=64)\end{array}$ & $\begin{array}{r}41 \\
(n=90)\end{array}$ & $\begin{array}{r}33 \\
(n=63)\end{array}$ & $\begin{array}{r}24 \\
(n=22)\end{array}$ \\
\hline 6 & $\begin{array}{r}0 \\
(n=4)\end{array}$ & $\begin{array}{r}1 \\
(n=2)\end{array}$ & $\begin{array}{r}13 \\
(n=31)\end{array}$ & $\begin{array}{r}12 \\
(n=29)\end{array}$ & $\begin{array}{r}18 \\
(n=39)\end{array}$ & $\begin{array}{r}10 \\
(n=28)\end{array}$ & $\begin{array}{r}16 \\
(n=35)\end{array}$ & $\begin{array}{r}21 \\
(n=21)\end{array}$ \\
\hline 7 & 0 & 0 & $\begin{array}{r}2 \\
(n=14)\end{array}$ & $\begin{array}{r}2 \\
(n=17)\end{array}$ & $\begin{array}{r}7 \\
(n=36)\end{array}$ & $\begin{array}{r}2 \\
(n=16)\end{array}$ & $\begin{array}{r}14 \\
(n=51)\end{array}$ & $\begin{array}{r}51 \\
(n=130)\end{array}$ \\
\hline
\end{tabular}
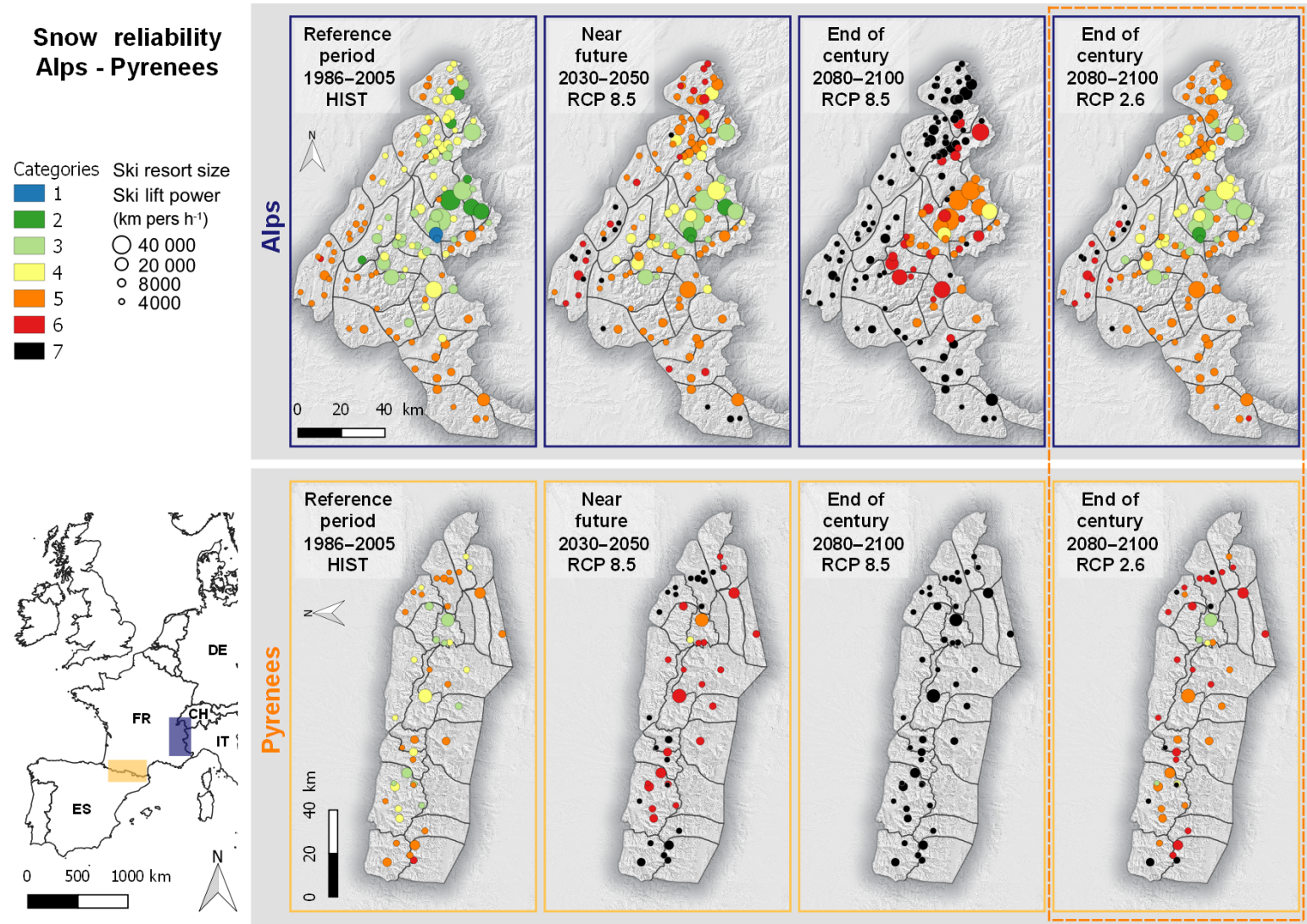

Figure 5. Fraction of ski lift power (\%) for a given category (Sect. 2.3). Categories 1, 2 and 3 illustrate ski resorts where natural snow conditions are reliable. Categories 4 and 5 illustrate ski resorts where snow conditions are reliable with snowmaking. Categories 6 and 7 illustrate ski resorts where snowmaking is no longer efficient in reducing the effect of natural snow scarcity at the lowest elevations of the resort. 


\section{Discussion}

A number of limitations remain in our approach and should be carefully considered in the interpretation of our results. Concerning the modelling of the snowpack evolution under past and future climate conditions, meteorological forcing data are aggregated at the scale of a massif (an approximately $1000 \mathrm{~km}^{2}$ surface area) and by elevation steps of $300 \mathrm{~m}$, which is a significant improvement compared to previous investigations (Abegg et al., 2007; Damm et al., 2017) although local effects are still neglected. The snow melting rate is probably underestimated in the model leading to somewhat optimistic results (Spandre et al., 2016b). The main reason for this is the one-dimensional assumption in the snowpack model neglecting the snow-ground partitioning, particularly when the natural snow melts out and leaves the ski slope as an isolated snow patch in grass or rock fields (Mott et al., 2015). This situation is likely to be more frequent under future climate conditions, resulting in increasingly optimistic results compared to the reference period. Additionally, all results computed based on the observational reference dataset and climate models exhibit differences in the reference period (Figs. 3 and 4 and Table 2). Discrepancies may be due to potential biases of the multivariate distribution of the meteorological variables produced by the adjustment and downscaling method (Verfaillie et al., 2017). This could result in potential nonlinear effects due to multiple dependencies, especially on temperature, relative humidity, precipitation and wind speed.

Beyond the modelling of snow conditions, the main limitations pertain to the snow reliability line approach. Singlepoint representations are considered on a flat field, i.e. neglecting the aspect and slope angles of a given ski area, which is of high importance in the seasonal evolution of the snowpack and might highly differ from one resort to another. These representations also neglect that all slopes are not covered by snowmaking facilities, hampering any detailed investigation of the evolution of water requirements (results are limited to values per unit surface area). Modelling chains including spatial representations of ski resorts may overcome such weaknesses of the snow reliability line approach (Spandre et al., 2018). Additionally, even though snowmaking may appear to be an efficient method to technically reduce the impacts of natural snow scarcity, the attractiveness of a given resort may be damaged due to either the lack of snow in parts of the ski resort not equipped with facilities or even the lack of natural snow (landscapes, winter spirit).

We provided information beyond a binary assessment of reliable or unreliable by creating reliability categories, although economic implications should be specifically investigated with a more detailed approach. For example, the relative economic importance of specific periods (Christmas and Winter school holidays) is also neglected in this approach, similarly to previous uses of the snow reliability line. More importantly, our study highlights ski resorts which, un- der present climate conditions, exhibit challenging snow reliability indicators (category 5 ski resorts in outer northern Alps regions, the southernmost southern Alps, and the eastern and western parts of the Pyrenees), but are currently operational. This indicates that snow reliability is only one factor of the socio-economic performance of ski resorts. This corroborates that the assessment of the sustainability of winter ski tourism destinations must encompass dimensions other than snow conditions alone, consistent with earlier findings (Luthe et al., 2012).

\section{Conclusion}

State-of-the-art snowpack modelling and climate projections were used in the present investigation to provide a snow reliability assessment of a large sample of 175 ski resorts in the French Alps and Pyrenees (France, Andorra and Spain) under past and future climate conditions. We report on a significant spatial variability in snow reliability, with or without snowmaking. The northern Alps showed the best natural snow conditions for the reference period (1986-2005) and under future climate conditions. Snowmaking appears to be an efficient method to improve the snow reliability with $99 \%$ of ski lift facilities reliable with snowmaking for the reference period. This is particularly true in the southern Alps where snowmaking leads to a lower elevation of the snowmaking reliability compared to the Pyrenees, while the natural snow reliability line is higher. This situation is projected to remain in future climate conditions and snow reliability elevation is projected to significantly rise due to the decrease in natural snow conditions and the suitable conditions for snowmaking. The difference between projected deviation between climate scenarios is very low in the near future (2030-2050). Depending on the RCP, $21 \%$ to $32 \%$ of ski lift infrastructures would remain reliable based on natural snow conditions while another $14 \%$ to $25 \%$ might be considered in a critical situation, i.e. for which snowmaking reliability can not be achieved. Significant snowmaking requirements are projected to be necessary at the snow reliability line ranging between 400 and $700 \mathrm{~kg} \mathrm{~m}^{-2}$, i.e. an equivalent 80 to $140 \mathrm{~cm}$ of machine-made snow production. Deviations between climate scenarios only appear after the mid-century with limited changes compared to the near future (RCP2.6) or continuous decrease in the snow reliability (RCP8.5). At the end of the century and for RCP8.5, our projections indicate that there would not remain any reliable resort based on natural snow conditions and only 24 resorts ( $28 \%$ of ski lift facilities) would benefit from snowmaking reliability, all being located in the Alps.

The past and future snow reliability of ski resorts in the French Alps and Pyrenees is highly variable, and the present investigation illustrates the relevance of considering local situations rather than drawing general conclusions. We believe that our results might be substantial material for discussions 
of the relevance of snowmaking as a technical adaptation and the decision-making regarding investments in these facilities. Management implications and economic issues might also be derived from this approach, which should be extended to mid-elevation areas in France (Jura, Vosges, Massif Central). This also bears potential for wider extension including at the European scale taking advantage of the fact that the method does not require complex data to characterize ski resorts (village and mean ski lift elevation) and could be applied to simulations of natural and managed snow at the European scale (Morin et al., 2018).

Assessing the impact of climate change on the ski tourism economy requires not only an estimate of future changes of natural and managed snow conditions, which we provided here, but also additional information on water requirements for snowmaking and how it affects the environmental context and business model of the ski industry. While until the mid21 st century snowmaking appears to be an efficient adaptation option to reduce the climate change hazard to ski resort operating conditions, their environmental footprint and socio-economic functioning may be altered, thereby increasing the vulnerability dimension of the socio-ecological risk if the mountain tourism business model remains unchanged. Towards the end of the century, under high-emission climate change scenarios (RCP8.5), the snow reliability will severely be questioned for most ski resorts currently operating in the Pyrenees and the French Alps, with and without snowmaking, with increased climate change risk under the current mountain tourism business model. Regardless of the time period of interest, future studies are required to analyse and assess all dimensions of climate change impacts and risk to this key mountain economic sector, in France and many other places on Earth.
Data availability. The climate projections used in this study are available on the Drias portal: http://drias-climat.fr/ (last access: 24 April 2019). Model results are available upon request to the corresponding author. 


\section{Appendix A: Snow reliability elevation}

\section{A1 Reference period (1986-2005)}

Table A1. Snow reliability elevation for the reference period (1986-2005) for the 42 massifs distributed over the northern Alps, southern Alps, French Pyrenees, and Spanish and Andorran Pyrenees, computed by the reference dataset (SAFRAN) and the climate models (HIST) for three distinct reliability requirements $(50 \%, 70 \%$ and $90 \%)$.

\begin{tabular}{|c|c|c|c|c|c|c|c|c|c|c|c|c|}
\hline \multirow[b]{3}{*}{ Massif } & \multicolumn{6}{|c|}{ Groomed snow } & \multicolumn{6}{|c|}{ Including snowmaking } \\
\hline & \multicolumn{3}{|c|}{$\begin{array}{l}\text { SAFRAN } \\
\text { (quantiles) }\end{array}$} & \multicolumn{3}{|c|}{$\begin{array}{c}\text { HIST } \\
\text { (quantiles) }\end{array}$} & \multicolumn{3}{|c|}{$\begin{array}{l}\text { SAFRAN } \\
\text { (quantiles) }\end{array}$} & \multicolumn{3}{|c|}{$\begin{array}{c}\text { HIST } \\
\text { (quantiles) }\end{array}$} \\
\hline & $50 \%$ & $70 \%$ & $90 \%$ & $50 \%$ & $70 \%$ & $90 \%$ & $50 \%$ & $70 \%$ & $90 \%$ & $50 \%$ & $70 \%$ & $90 \%$ \\
\hline \multicolumn{13}{|l|}{ Northern Alps } \\
\hline Chablais & 1240 & 1410 & 1630 & 1350 & 1580 & 1940 & 450 & 670 & 930 & 450 & 630 & 780 \\
\hline Aravis & 1220 & 1370 & 1620 & 1310 & 1540 & 1910 & 750 & 750 & 750 & 750 & 750 & 750 \\
\hline Mont Blanc & 1160 & 1390 & 1580 & 1350 & 1580 & 1930 & 1050 & 1050 & 1050 & 1050 & 1050 & 1050 \\
\hline Bauges & 1190 & 1440 & 1670 & 1340 & 1590 & 1970 & 450 & 450 & 650 & 450 & 450 & 730 \\
\hline Beaufortain & 1270 & 1430 & 1660 & 1350 & 1620 & 2100 & 750 & 750 & 750 & 750 & 750 & 750 \\
\hline Haute-Tarentaise & 1450 & 1560 & 1720 & 1470 & 1800 & 2280 & 750 & 750 & 750 & 750 & 750 & 750 \\
\hline Chartreuse & 1310 & 1490 & 1740 & 1420 & 1830 & 2070 & 450 & 680 & 770 & 450 & 650 & 860 \\
\hline Belledonne & 1380 & 1510 & 1650 & 1420 & 1650 & 1960 & 450 & 650 & 770 & 450 & 450 & 750 \\
\hline Maurienne & 1450 & 1550 & 1740 & 1420 & 1740 & 2160 & 450 & 620 & 780 & 450 & 450 & 690 \\
\hline Vanoise & 1490 & 1690 & 1780 & 1460 & 1830 & 2230 & 750 & 750 & 750 & 750 & 750 & 750 \\
\hline Haute-Maurienne & 1910 & 2050 & 2480 & 2070 & 2270 & 2520 & 1050 & 1050 & 1050 & 1050 & 1050 & 1050 \\
\hline Grandes-Rousses & 1660 & 1790 & 2170 & 1700 & 1940 & 2440 & 750 & 750 & 780 & 750 & 750 & 750 \\
\hline Vercors & 1490 & 1700 & 1860 & 1580 & 1800 & 2150 & 620 & 850 & 1050 & 640 & 790 & 1020 \\
\hline Oisans & 1690 & 1870 & 2230 & 1740 & 1970 & 2320 & 750 & 800 & 1030 & 750 & 750 & 770 \\
\hline \multicolumn{13}{|l|}{ Southern Alps } \\
\hline Thabor & 1820 & 2040 & 2590 & 1850 & 2060 & 2470 & 1350 & 1350 & 1350 & 1350 & 1350 & 1350 \\
\hline Pelvoux & 1630 & 2010 & 2690 & 1800 & 2020 & 2430 & 1050 & 1050 & 1050 & 1050 & 1050 & 1050 \\
\hline Queyras & 2150 & 2480 & 2940 & 2210 & 2370 & 2790 & 1050 & 1050 & 1050 & 1050 & 1050 & 1050 \\
\hline Dévoluy & 1820 & 2030 & 2470 & 1840 & 2090 & 2470 & 780 & 1100 & 1280 & 750 & 900 & 1160 \\
\hline Champsaur & 1680 & 1990 & 2540 & 1850 & 2080 & 2510 & 1050 & 1050 & 1050 & 1050 & 1050 & 1050 \\
\hline Embrunnais Parpaillon & 2110 & 2520 & 2960 & 2040 & 2260 & 2810 & 750 & 940 & 1170 & 750 & 750 & 960 \\
\hline Ubaye & 2250 & 2560 & 2940 & 2300 & 2530 & 2910 & 1050 & 1050 & 1230 & 1050 & 1050 & 1050 \\
\hline Haut-Var Haut-Verdon & 2140 & 2330 & 2580 & 2060 & 2280 & 2690 & 960 & 1230 & 1350 & 900 & 1080 & 1300 \\
\hline Mercantour & 2210 & 2360 & 2760 & 2100 & 2330 & 2740 & 1050 & 1280 & 1360 & 1050 & 1240 & 1390 \\
\hline \multicolumn{13}{|l|}{ French Pyrenees } \\
\hline Aspe Ossau & 1480 & 1620 & 1930 & 1740 & 1970 & 2210 & 960 & 1050 & 1400 & 1080 & 1220 & 1400 \\
\hline Haute-Bigorre & 1670 & 1730 & 1950 & 1770 & 1980 & 2220 & 970 & 1060 & 1380 & 910 & 1080 & 1260 \\
\hline Aure Louron & 1630 & 1860 & 1940 & 1830 & 2010 & 2270 & 930 & 990 & 1310 & 850 & 980 & 1210 \\
\hline Luchonnais & 1650 & 1830 & 2020 & 1860 & 2020 & 2280 & 890 & 960 & 1420 & 750 & 900 & 1180 \\
\hline Couserans & 1430 & 1620 & 1770 & 1560 & 1740 & 2050 & 900 & 1000 & 1180 & 800 & 930 & 1130 \\
\hline Haute-Ariège & 1490 & 1640 & 1760 & 1690 & 1850 & 2140 & 890 & 970 & 1240 & 800 & 940 & 1130 \\
\hline Orlu St-Barthélémy & 1580 & 1680 & 1800 & 1720 & 1880 & 2240 & 1050 & 1230 & 1310 & 1060 & 1170 & 1330 \\
\hline Capcir-Puymorens & 2050 & 2380 & 2580 & 2320 & 2570 & 2850 & 1200 & 1310 & 1540 & 1050 & 1260 & 1530 \\
\hline Cerdagne-Canigou & 2180 & 2360 & 2710 & 2320 & 2600 & 3000 & 1180 & 1310 & 1600 & 1180 & 1310 & 1550 \\
\hline \multicolumn{13}{|c|}{ Spanish and Andorran Pyrenees } \\
\hline Andor & 1790 & 1990 & 2370 & 1930 & & 2530 & 920 & 1130 & 1290 & 860 & 1080 & 1290 \\
\hline Jacetania & 1860 & 1930 & 2010 & 2010 & 2140 & 2340 & 1180 & 1280 & 1470 & 1170 & 1350 & 1530 \\
\hline Gallego & 1780 & 1900 & 2040 & 2060 & 2240 & 2440 & 1110 & 1160 & 1360 & 1110 & 1240 & 1470 \\
\hline Esera & 2050 & 2260 & 2360 & 2150 & 2290 & 2560 & 1040 & 1170 & 1590 & 840 & 1020 & 1340 \\
\hline Aran & 1950 & 2070 & 2200 & 2080 & 2330 & 2630 & 1020 & 1140 & 1460 & 920 & 1110 & 1330 \\
\hline Ribagorçana & 1960 & 2200 & 2350 & 2110 & 2300 & 2650 & 1070 & 1150 & 1340 & 890 & 1070 & 1340 \\
\hline Pallaresa & 1900 & 2150 & 2450 & 2040 & 2260 & 2640 & 930 & 1050 & 1300 & 750 & 950 & 1200 \\
\hline Ter-Freser & 2060 & 2570 & 2810 & 2060 & 2350 & 2780 & 1250 & 1320 & 1650 & 1130 & 1290 & 1440 \\
\hline Cadi Moixero & 2010 & 2070 & 2450 & 2280 & 2530 & 2850 & 1060 & 1170 & 1460 & 980 & 1180 & 1380 \\
\hline Pre-Pyrenees & 1960 & 2060 & 2250 & 2190 & 2250 & 2250 & 1020 & 1230 & 1370 & 980 & 1180 & 1420 \\
\hline
\end{tabular}




\section{A2 Near future (2030-2050)}

Table A2. Snow reliability elevation for the near future (2030-2050) for the 42 massifs distributed over the northern Alps, southern Alps, French Pyrenees, and Spanish and Andorran Pyrenees, computed by climate models for the RCP2.6, RCP4.5 and RCP8.5 and for three reliability requirements $(50 \%, 70 \%$ and $90 \%)$.

\begin{tabular}{|c|c|c|c|c|c|c|c|c|c|c|c|c|c|c|c|c|c|c|}
\hline \multirow[b]{3}{*}{ Massif } & \multicolumn{9}{|c|}{ Groomed snow } & \multicolumn{9}{|c|}{ Including snowmaking } \\
\hline & \multicolumn{3}{|c|}{$\begin{array}{l}\mathrm{RCP} 2.6 \\
\text { (quantiles) }\end{array}$} & \multicolumn{3}{|c|}{$\begin{array}{l}\text { RCP4.5 } \\
\text { (quantiles) }\end{array}$} & \multicolumn{3}{|c|}{$\begin{array}{l}\text { RCP8.5 } \\
\text { (quantiles) }\end{array}$} & \multicolumn{3}{|c|}{$\begin{array}{l}\mathrm{RCP} 2.6 \\
\text { (quantiles) }\end{array}$} & \multicolumn{3}{|c|}{$\begin{array}{l}\text { RCP4.5 } \\
\text { (quantiles) }\end{array}$} & \multicolumn{3}{|c|}{$\begin{array}{l}\text { RCP8.5 } \\
\text { (quantiles) }\end{array}$} \\
\hline & $50 \%$ & $70 \%$ & $90 \%$ & $50 \%$ & $70 \%$ & $90 \%$ & $50 \%$ & $70 \%$ & $90 \%$ & $50 \%$ & $70 \%$ & $90 \%$ & $50 \%$ & $70 \%$ & $90 \%$ & $50 \%$ & $70 \%$ & $90 \%$ \\
\hline \multicolumn{19}{|l|}{ Northern Alps } \\
\hline Chablais & 1710 & 1920 & 2150 & 1600 & 1860 & 2030 & 1680 & 1930 & 2260 & 530 & 800 & 880 & 690 & 850 & 990 & 680 & 840 & 1050 \\
\hline Aravis & 1580 & 1800 & 2400 & 1510 & 1720 & 1990 & 1580 & 1800 & 2140 & 750 & 750 & 750 & 750 & 750 & 920 & 750 & 750 & 980 \\
\hline Mont Blanc & 1700 & 1900 & 2160 & 1510 & 1750 & 2030 & 1630 & 1830 & 2120 & 1050 & 1050 & 1050 & 1050 & 1050 & 1050 & 1050 & 1050 & 1050 \\
\hline Bauges & 1720 & 1970 & 2180 & 1590 & 1860 & 2160 & 1580 & 1930 & 2250 & 450 & 710 & 940 & 450 & 750 & 1050 & 450 & 780 & 1050 \\
\hline Beaufortain & 1620 & 1850 & 2330 & 1560 & 1750 & 2130 & 1630 & 1870 & 2280 & 750 & 750 & 750 & 750 & 750 & 770 & 750 & 750 & 930 \\
\hline Haute-Tarentaise & 1780 & 2100 & 2490 & 1650 & 1850 & 2250 & 1730 & 2030 & 2420 & 750 & 750 & 750 & 750 & 750 & 750 & 750 & 750 & 750 \\
\hline Chartreuse & 1870 & 2030 & 2250 & 1760 & 2020 & 2250 & 1840 & 2040 & 2250 & 770 & 880 & 1080 & 700 & 900 & 1150 & 720 & 930 & 1220 \\
\hline Belledonne & 1660 & 1890 & 2120 & 1610 & 1840 & 2110 & 1690 & 1910 & 2260 & 610 & 720 & 950 & 640 & 780 & 1010 & 660 & 820 & 1080 \\
\hline Maurienne & 1770 & 1990 & 2460 & 1640 & 1860 & 2160 & 1680 & 1930 & 2400 & 450 & 740 & 840 & 450 & 730 & 920 & 450 & 740 & 950 \\
\hline Vanoise & 1740 & 2050 & 2490 & 1630 & 1840 & 2200 & 1740 & 1980 & 2400 & 750 & 750 & 750 & 750 & 750 & 750 & 750 & 750 & 750 \\
\hline Haute-Maurienne & 2320 & 2470 & 2680 & 2200 & 2360 & 2670 & 2290 & 2460 & 2810 & 1050 & 1050 & 1050 & 1050 & 1050 & 1050 & 1050 & 1050 & 1050 \\
\hline Grandes-Rousses & 1990 & 2220 & 2570 & 1910 & 2100 & 2540 & 1940 & 2210 & 2610 & 750 & 750 & 960 & 750 & 750 & 1010 & 750 & 750 & 1100 \\
\hline Vercors & 1870 & 2030 & 2550 & 1910 & 2070 & 2400 & 1930 & 2140 & 2480 & 850 & 1020 & 1300 & 870 & 1030 & 1330 & 880 & 1080 & 1380 \\
\hline Oisans & 1870 & 2180 & 2660 & 1940 & 2160 & 2560 & 2020 & 2280 & 2660 & 750 & 750 & 1020 & 750 & 750 & 1090 & 750 & 940 & 1200 \\
\hline \multicolumn{19}{|l|}{ Southern Alps } \\
\hline Thabor & 2110 & 2410 & 2640 & 2050 & 2220 & 2580 & 2130 & 2440 & 2810 & 1350 & 1350 & 1350 & 1350 & 1350 & 1350 & 1350 & 1350 & 1350 \\
\hline Pelvoux & 1990 & 2180 & 2900 & 1930 & 2190 & 2640 & 2050 & 2330 & 2820 & 1050 & 1050 & 1050 & 1050 & 1050 & 1050 & 1050 & 1050 & 1050 \\
\hline Queyras & 2340 & 2620 & 3150 & 2320 & 2540 & 2900 & 2400 & 2690 & 3150 & 1050 & 1050 & 1050 & 1050 & 1050 & 1050 & 1050 & 1050 & 1050 \\
\hline Dévoluy & 2010 & 2250 & 2660 & 2100 & 2330 & 2650 & 2190 & 2430 & 2810 & 920 & 1150 & 1390 & 1000 & 1200 & 1430 & 1020 & 1270 & 1460 \\
\hline Champsaur & 2010 & 2260 & 2790 & 2030 & 2310 & 2660 & 2190 & 2420 & 2880 & 1050 & 1050 & 1050 & 1050 & 1050 & 1050 & 1050 & 1050 & 1050 \\
\hline Embrunnais Parpaillon & 2240 & 2480 & 3090 & 2190 & 2500 & 2950 & 2320 & 2640 & 3060 & 750 & 750 & 1020 & 750 & 960 & 1100 & 750 & 980 & 1160 \\
\hline Ubaye & 2360 & 2860 & 3150 & 2460 & 2770 & 3120 & 2590 & 2870 & 3150 & 1050 & 1050 & 1330 & 1050 & 1050 & 1410 & 1050 & 1050 & 1560 \\
\hline Haut-Var Haut-Verdon & 2330 & 2620 & 2850 & 2300 & 2560 & 2850 & 2340 & 2650 & 2850 & 1140 & 1280 & 1500 & 1200 & 1350 & 1590 & 1200 & 1400 & 1690 \\
\hline Mercantour & 2380 & 2640 & 3150 & 2350 & 2560 & 2880 & 2450 & 2680 & 3150 & 1250 & 1370 & 1560 & 1310 & 1430 & 1600 & 1330 & 1470 & 1690 \\
\hline \multicolumn{19}{|l|}{ French Pyrenees } \\
\hline Aspe Ossau & 2000 & 2230 & 2480 & 2030 & 2280 & 2470 & 2070 & 2320 & 2590 & 1360 & 1500 & 1770 & 1380 & 1570 & 1870 & 1370 & 1570 & 2020 \\
\hline Haute-Bigorre & 2070 & 2280 & 2690 & 2050 & 2230 & 2620 & 2080 & 2300 & 2820 & 1300 & 1480 & 1690 & 1220 & 1470 & 1710 & 1190 & 1460 & 1850 \\
\hline Aure Louron & 2090 & 2340 & 2590 & 2050 & 2280 & 2590 & 2110 & 2370 & 2790 & 1260 & 1460 & 1700 & 1130 & 1350 & 1690 & 1140 & 1420 & 1870 \\
\hline Luchonnais & 2070 & 2340 & 2590 & 2040 & 2270 & 2630 & 2080 & 2320 & 2660 & 1180 & 1400 & 1670 & 1140 & 1360 & 1700 & 1100 & 1380 & 1850 \\
\hline Couserans & 1920 & 2120 & 2340 & 1830 & 2020 & 2330 & 1900 & 2100 & 2430 & 1120 & 1310 & 1520 & 1060 & 1220 & 1470 & 1110 & 1310 & 1600 \\
\hline Haute-Ariège & 1960 & 2140 & 2380 & 1970 & 2080 & 2450 & 2010 & 2120 & 2560 & 1120 & 1300 & 1460 & 1070 & 1260 & 1470 & 1070 & 1270 & 1600 \\
\hline Orlu St-Barthélémy & 2040 & 2280 & 2540 & 1950 & 2070 & 2540 & 2010 & 2200 & 2630 & 1280 & 1410 & 1630 & 1290 & 1430 & 1640 & 1280 & 1460 & 1750 \\
\hline Capcir-Puymorens & 2640 & 2850 & 2850 & 2580 & 2760 & 2850 & 2640 & 2820 & 2850 & 1450 & 1650 & 1860 & 1440 & 1600 & 1770 & 1400 & 1620 & 2040 \\
\hline Cerdagne-Canigou & 2610 & 2850 & 3150 & 2590 & 2860 & 3150 & 2640 & 2960 & 3150 & 1480 & 1630 & 1810 & 1450 & 1590 & 1800 & 1460 & 1650 & 1960 \\
\hline \multicolumn{19}{|c|}{ Spanish and Andorran Pyrenees } \\
\hline Andorra & 2250 & 2550 & 2870 & 2140 & 2400 & 2820 & 2270 & 2580 & 3020 & 1290 & 1360 & 1540 & 1260 & 1390 & 1520 & 1290 & 1420 & 1720 \\
\hline Jacetiana & 2280 & 2400 & 2600 & 2300 & 2380 & 2630 & 2320 & 2490 & 2850 & 1460 & 1680 & 1900 & 1550 & 1710 & 1920 & 1570 & 1760 & 1980 \\
\hline Gallego & 2290 & 2410 & 2630 & 2310 & 2390 & 2650 & 2340 & 2600 & 3060 & 1450 & 1610 & 1800 & 1420 & 1630 & 1830 & 1460 & 1700 & 1980 \\
\hline Esera & 2360 & 2620 & 2920 & 2360 & 2580 & 2830 & 2430 & 2660 & 3190 & 1310 & 1480 & 1700 & 1200 & 1450 & 1690 & 1320 & 1510 & 1930 \\
\hline Aran & 2350 & 2660 & 3010 & 2340 & 2620 & 2960 & 2340 & 2610 & 3150 & 1260 & 1390 & 1700 & 1200 & 1370 & 1640 & 1230 & 1430 & 1830 \\
\hline Ribagorçana & 2350 & 2590 & 2930 & 2380 & 2600 & 2870 & 2500 & 2670 & 3150 & 1350 & 1450 & 1770 & 1230 & 1420 & 1660 & 1300 & 1500 & 1880 \\
\hline Pallaresa & 2350 & 2560 & 2870 & 2370 & 2590 & 2890 & 2450 & 2670 & 3140 & 1150 & 1320 & 1580 & 1140 & 1350 & 1580 & 1170 & 1430 & 1780 \\
\hline Ter-Freser & 2370 & 2570 & 3000 & 2410 & 2690 & 3150 & 2510 & 2850 & 3150 & 1430 & 1530 & 1750 & 1410 & 1530 & 1740 & 1460 & 1570 & 1860 \\
\hline Cadi Moixero & 2540 & 2850 & 2850 & 2600 & 2770 & 2850 & 2630 & 2850 & 2850 & 1350 & 1480 & 1750 & 1310 & 1490 & 1710 & 1380 & 1560 & 1920 \\
\hline Pre-Pyrenees & 2250 & 2250 & 2250 & 2250 & 2250 & 2250 & 2250 & 2250 & 2250 & 1310 & 1460 & 1780 & 1340 & 1500 & 1780 & 1360 & 1580 & 1950 \\
\hline
\end{tabular}




\section{A3 End of the century (2080-2100)}

Table A3. Snow reliability elevation for the end of the century (2080-2100) for the 42 massifs distributed over the northern Alps, southern Alps, French Pyrenees, and Spanish and Andorran Pyrenees, computed by climate models for the RCP2.6, RCP4.5 and RCP8.5 and for three reliability requirements $(50 \%, 70 \%$ and $90 \%)$.

\begin{tabular}{|c|c|c|c|c|c|c|c|c|c|c|c|c|c|c|c|c|c|c|}
\hline \multirow[b]{3}{*}{ Massif } & \multicolumn{9}{|c|}{ Groomed snow } & \multicolumn{9}{|c|}{ Including snowmaking } \\
\hline & \multicolumn{3}{|c|}{$\begin{array}{c}\text { RCP2.6 } \\
\text { (quantiles) }\end{array}$} & \multicolumn{3}{|c|}{$\begin{array}{l}\text { RCP4.5 } \\
\text { (quantiles) }\end{array}$} & \multicolumn{3}{|c|}{$\begin{array}{l}\text { RCP8.5 } \\
\text { (quantiles) }\end{array}$} & \multicolumn{3}{|c|}{$\begin{array}{c}\text { RCP2.6 } \\
\text { (quantiles) }\end{array}$} & \multicolumn{3}{|c|}{$\begin{array}{c}\text { RCP4.5 } \\
\text { (quantiles) }\end{array}$} & \multicolumn{3}{|c|}{$\begin{array}{l}\text { RCP8.5 } \\
\text { (quantiles) }\end{array}$} \\
\hline & $50 \%$ & $70 \%$ & $90 \%$ & $50 \%$ & $70 \%$ & $90 \%$ & $50 \%$ & $70 \%$ & $90 \%$ & $50 \%$ & $70 \%$ & $90 \%$ & $50 \%$ & $70 \%$ & $90 \%$ & $50 \%$ & $70 \%$ & $90 \%$ \\
\hline \multicolumn{19}{|l|}{ Northern Alps } \\
\hline Chablais & 1640 & 1880 & 2330 & 1820 & 2060 & 2560 & 2380 & 2640 & 2850 & 630 & 790 & 930 & 750 & 900 & 1090 & 1100 & 1350 & 1980 \\
\hline Aravis & 1490 & 1780 & 2290 & 1700 & 1950 & 2480 & 2330 & 2610 & 2850 & 750 & 750 & 750 & 750 & 750 & 1030 & 1010 & 1200 & 1850 \\
\hline Mont Blanc & 1570 & 1810 & 2390 & 1710 & 1950 & 2520 & 2310 & 2570 & 2900 & 1050 & 1050 & 1050 & 1050 & 1050 & 1050 & 1050 & 1050 & 1660 \\
\hline Bauges & 1660 & 1980 & 2250 & 1780 & 2090 & 2250 & 2250 & 2250 & 2250 & 450 & 750 & 960 & 650 & 880 & 1240 & 1200 & 1640 & 2100 \\
\hline Beaufortain & 1640 & 1820 & 2200 & 1730 & 1960 & 2600 & 2290 & 2570 & 3070 & 750 & 750 & 950 & 750 & 750 & 1000 & 1000 & 1130 & 1680 \\
\hline Haute-Tarentaise & 1750 & 2160 & 2500 & 1820 & 2160 & 2820 & 2330 & 2670 & 3160 & 750 & 750 & 750 & 750 & 750 & 940 & 750 & 950 & 1140 \\
\hline Chartreuse & 1830 & 2070 & 2250 & 2010 & 2250 & 2250 & 2250 & 2250 & 2250 & 700 & 950 & 1240 & 770 & 1060 & 1670 & 1790 & 1990 & 2220 \\
\hline Belledonne & 1630 & 1800 & 2250 & 1800 & 2050 & 2560 & 2360 & 2610 & 3000 & 450 & 750 & 950 & 730 & 870 & 1190 & 1250 & 1620 & 2000 \\
\hline Maurienne & 1780 & 1950 & 2370 & 1770 & 2090 & 2780 & 2330 & 2670 & 3120 & 450 & 690 & 980 & 680 & 810 & 1050 & 970 & 1170 & 1520 \\
\hline Vanoise & 1720 & 2020 & 2470 & 1760 & 2140 & 2770 & 2320 & 2610 & 3080 & 750 & 750 & 750 & 750 & 750 & 750 & 750 & 1090 & 1440 \\
\hline Haute-Maurienne & 2320 & 2500 & 2800 & 2360 & 2610 & 2930 & 2710 & 2970 & 3360 & 1050 & 1050 & 1050 & 1050 & 1050 & 1050 & 1050 & 1050 & 1500 \\
\hline Grandes-Rousses & 1930 & 2210 & 2560 & 2010 & 2380 & 2810 & 2570 & 2850 & 3240 & 750 & 750 & 1000 & 750 & 750 & 1160 & 1120 & 1390 & 1830 \\
\hline Vercors & 1830 & 2130 & 2550 & 2050 & 2310 & 2550 & 2550 & 2550 & 2550 & 920 & 1100 & 1300 & 980 & 1310 & 1660 & 1750 & 2020 & 2360 \\
\hline Oisans & 1990 & 2160 & 2800 & 2090 & 2430 & 2900 & 2630 & 2890 & 3430 & 750 & 750 & 1000 & 750 & 1020 & 1290 & 1220 & 1580 & 1940 \\
\hline \multicolumn{19}{|l|}{ Southern Alps } \\
\hline Thabor & 2150 & 2400 & 2720 & 2250 & 2570 & 2900 & 2790 & 2990 & 3150 & 1350 & 1350 & 1350 & 1350 & 1350 & 1350 & 1350 & 1350 & 1740 \\
\hline Pelvoux & 2110 & 2340 & 2850 & 2140 & 2450 & 2900 & 2660 & 2960 & 3400 & 1050 & 1050 & 1050 & 1050 & 1050 & 1050 & 1050 & 1050 & 1410 \\
\hline Queyras & 2460 & 2690 & 3150 & 2610 & 2900 & 3150 & 2980 & 3150 & 3150 & 1050 & 1050 & 1050 & 1050 & 1050 & 1050 & 1050 & 1240 & 1480 \\
\hline Dévoluy & 2070 & 2330 & 2640 & 2330 & 2570 & 2880 & 2880 & 3060 & 3150 & 1050 & 1230 & 1380 & 1160 & 1320 & 1700 & 1730 & 2000 & 2330 \\
\hline Champsaur & 2180 & 2440 & 2820 & 2330 & 2560 & 3020 & 2820 & 3120 & 3450 & 1050 & 1050 & 1050 & 1050 & 1050 & 1050 & 1050 & 1350 & 1710 \\
\hline Embrunnais Parpaillon & 2430 & 2640 & 3060 & 2510 & 2820 & 3220 & 2970 & 3220 & 3450 & 750 & 750 & 1020 & 750 & 1060 & 1210 & 1300 & 1620 & 2130 \\
\hline Ubaye & 2610 & 2890 & 3150 & 2760 & 2970 & 3150 & 3030 & 3150 & 3150 & 1050 & 1050 & 1300 & 1050 & 1250 & 1660 & 1560 & 1880 & 2320 \\
\hline Haut-Var Haut-Verdon & 2330 & 2560 & 2850 & 2540 & 2780 & 2850 & 2850 & 2850 & 2850 & 1160 & 1330 & 1560 & 1300 & 1540 & 1850 & 1900 & 2090 & 2410 \\
\hline Mercantour & 2300 & 2570 & 2880 & 2590 & 2820 & 3150 & 3020 & 3150 & 3150 & 1270 & 1340 & 1510 & 1370 & 1500 & 1760 & 1750 & 1990 & 2480 \\
\hline \multicolumn{19}{|l|}{ French Pyrenees } \\
\hline Aspe Ossau & 2000 & 2190 & 2540 & 2260 & 2400 & 2650 & 2780 & 2940 & 3150 & 1350 & 1470 & 1840 & 1480 & 1750 & 2130 & 2180 & 2380 & 2840 \\
\hline Haute-Bigorre & 2000 & 2180 & 2480 & 2250 & 2380 & 2980 & 2990 & 3200 & 3450 & 1290 & 1470 & 1610 & 1400 & 1620 & 1890 & 1990 & 2220 & 3060 \\
\hline Aure Louron & 2030 & 2190 & 2650 & 2310 & 2490 & 2880 & 2900 & 3150 & 3150 & 1130 & 1300 & 1720 & 1340 & 1670 & 1960 & 1980 & 2180 & 2720 \\
\hline Luchonnais & 2000 & 2220 & 2740 & 2280 & 2550 & 2860 & 2900 & 3150 & 3450 & 1160 & 1360 & 1750 & 1330 & 1600 & 1950 & 1990 & 2180 & 2680 \\
\hline Couserans & 1840 & 2030 & 2350 & 2030 & 2260 & 2480 & 2600 & 2830 & 3150 & 1060 & 1230 & 1490 & 1250 & 1400 & 1700 & 1830 & 2020 & 2560 \\
\hline Haute-Ariège & 1910 & 2050 & 2410 & 2060 & 2330 & 2790 & 2770 & 3010 & 3150 & 1050 & 1220 & 1480 & 1180 & 1410 & 1690 & 1760 & 2020 & 2590 \\
\hline Orlu St-Barthélémy & 1910 & 2140 & 2370 & 2100 & 2440 & 2840 & 2690 & 2850 & 2850 & 1260 & 1410 & 1630 & 1380 & 1570 & 1850 & 1900 & 2140 & 2680 \\
\hline Capcir Puymorens & 2510 & 2690 & 2850 & 2710 & 2850 & 2850 & 2850 & 2850 & 2850 & 1430 & 1540 & 1800 & 1530 & 1740 & 2110 & 2170 & 2370 & 2770 \\
\hline Cerdagne Canigou & 2450 & 2640 & 3150 & 2770 & 3060 & 3150 & 3150 & 3150 & 3150 & 1470 & 1620 & 1830 & 1550 & 1730 & 2020 & 2010 & 2270 & 2750 \\
\hline \multicolumn{19}{|c|}{ Spanish and Andorran Pyrenees } \\
\hline Andorra & 2090 & 2240 & 2560 & 2360 & 2750 & 3150 & 3010 & 3150 & 3150 & 1230 & 1350 & 1600 & 1350 & 1490 & 1810 & 1870 & 2070 & 2640 \\
\hline Jacetiana & 2280 & 2410 & 2700 & 2360 & 2570 & 2810 & 2950 & 3150 & 3150 & 1470 & 1680 & 1910 & 1690 & 1870 & 2060 & 2190 & 2370 & 2810 \\
\hline Gallego & 2350 & 2510 & 2750 & 2390 & 2640 & 2990 & 3040 & 3150 & 3150 & 1390 & 1500 & 1730 & 1590 & 1780 & 2030 & 2140 & 2390 & 2880 \\
\hline Esera & 2440 & 2610 & 2950 & 2570 & 2790 & 3080 & 3060 & 3260 & 3450 & 1300 & 1500 & 1640 & 1460 & 1670 & 1940 & 2050 & 2230 & 2720 \\
\hline Aran & 2260 & 2520 & 2780 & 2570 & 2850 & 3150 & 3120 & 3150 & 3150 & 1120 & 1340 & 1620 & 1340 & 1550 & 1970 & 1940 & 2160 & 2720 \\
\hline Ribagorçana & 2350 & 2680 & 2950 & 2590 & 2820 & 3150 & 3040 & 3150 & 3150 & 1300 & 1500 & 1710 & 1460 & 1650 & 1910 & 2040 & 2250 & 2690 \\
\hline Pallaresa & 2350 & 2620 & 3020 & 2630 & 2840 & 3150 & 3130 & 3150 & 3150 & 1170 & 1340 & 1710 & 1390 & 1570 & 1880 & 2010 & 2200 & 2710 \\
\hline Ter-Freser & 2320 & 2600 & 3040 & 2670 & 2920 & 3150 & 3150 & 3150 & 3150 & 1370 & 1480 & 1730 & 1510 & 1670 & 1950 & 2020 & 2280 & 2740 \\
\hline Cadi Moixero & 2500 & 2850 & 2850 & 2730 & 2850 & 2850 & 2850 & 2850 & 2850 & 1350 & 1550 & 1800 & 1480 & 1690 & 2010 & 1990 & 2290 & 2850 \\
\hline Pre-Pyrenees & 2250 & 2250 & 2250 & 2250 & 2250 & 2250 & 2250 & 2250 & 2250 & 1210 & 1500 & 1800 & 1470 & 1710 & 1970 & 1970 & 2210 & 2250 \\
\hline
\end{tabular}


Appendix B: Detailed features of individual ski resorts

Table B1. Main features of the 175 ski resorts included in the present work grouped by massifs and major areas (northern and southern Alps, French and Spanish and Andorran Pyrenees).

\begin{tabular}{|c|c|c|c|c|c|}
\hline & \multicolumn{5}{|c|}{ Resort features } \\
\hline & $\begin{array}{l}\text { Ski lift } \\
\text { power }\end{array}$ & $\begin{array}{l}\text { Size } \\
\text { category }\end{array}$ & $\begin{array}{l}\text { Village } \\
\text { elevation }\end{array}$ & $\begin{array}{r}\text { Mean } \\
\text { elevation }\end{array}$ & $\begin{array}{r}\text { Max. } \\
\text { elevation }\end{array}$ \\
\hline \multicolumn{6}{|l|}{ Chablais (northern Alps) } \\
\hline Lullin-Col du Feu & 81 & $\mathrm{~S}$ & 1084 & 1130 & 1175 \\
\hline Plaine-Joux & 749 & $\mathrm{~S}$ & 1372 & 1508 & 1718 \\
\hline Abondance & 1205 & $\mathrm{~S}$ & 1049 & 1341 & 1758 \\
\hline Habère-Poche & 1454 & $\mathrm{~S}$ & 1018 & 1200 & 1505 \\
\hline Bellevaux Hirmentaz & 2115 & $\mathrm{~S}$ & 1185 & 1331 & 1612 \\
\hline Bernex & 2372 & $\mathrm{~S}$ & 1009 & 1396 & 1871 \\
\hline Thollon Les Mémises & 2468 & $\mathrm{~S}$ & 1048 & 1518 & 1938 \\
\hline Brasses (Les) & 2617 & $\mathrm{M}$ & 1148 & 1249 & 1495 \\
\hline Espace Roc d'Enfer & 3100 & $\mathrm{M}$ & 1013 & 1351 & 1790 \\
\hline Chapelle d'Abondance (la) & 3156 & M & 1054 & 1410 & 1797 \\
\hline Praz-de-Lys - Sommand & 5099 & $\mathrm{~L}$ & 1453 & 1487 & 1961 \\
\hline Carroz d'Arâches (Les) & 7348 & $\mathrm{~L}$ & 1160 & 1561 & 2109 \\
\hline Morzine Pleney Nyon & 9204 & $\mathrm{~L}$ & 1012 & 1467 & 2127 \\
\hline Gets (Les) & 10489 & $\mathrm{~L}$ & 1202 & 1502 & 2131 \\
\hline Morillon-Samoëns-Sixt & 12159 & $\mathrm{~L}$ & 968 & 1501 & 2118 \\
\hline Grand Massif (Flaine - Vallée du Giffre) & 13466 & $\mathrm{~L}$ & 1662 & 1982 & 2482 \\
\hline Châtel & 13959 & $\mathrm{~L}$ & 1208 & 1631 & 2093 \\
\hline Avoriaz - Morzine & 18826 & $\mathrm{XL}$ & 1758 & 1815 & 2501 \\
\hline \multicolumn{6}{|l|}{ Aravis (northern Alps) } \\
\hline Cret (Saint-Jean-de-Sixt) & 49 & $\mathrm{~S}$ & 959 & 843 & 1020 \\
\hline Montmin & 96 & $\mathrm{~S}$ & 1152 & 1101 & 1195 \\
\hline Reposoir (Le) & 271 & $\mathrm{~S}$ & 1039 & 1301 & 1626 \\
\hline Rafforts (Les) - Ugine & 285 & $\mathrm{~S}$ & 939 & 1067 & 1225 \\
\hline Nancy-sur-Cluses & 354 & $\mathrm{~S}$ & 1291 & 1341 & 1558 \\
\hline Mont-Saxonnex & 828 & $\mathrm{~S}$ & 1059 & 1346 & 1574 \\
\hline Portes du Mont-Blanc (Les) - Sallanches-Cordon & 1005 & $\mathrm{~S}$ & 1106 & 1315 & 1538 \\
\hline Manigod Croix Fry & 2088 & $\mathrm{~S}$ & 1502 & 1491 & 1795 \\
\hline $\begin{array}{l}\text { Portes du Mont-Blanc (Les) - Combloux - } \\
\text { Le Jaillet - La Giettaz }\end{array}$ & 4753 & M & 1152 & 1405 & 1982 \\
\hline Grand Bornand (Le) & 11400 & $\mathrm{~L}$ & 1254 & 1509 & 2031 \\
\hline Clusaz (La) & 13826 & $\mathrm{~L}$ & 1126 & 1612 & 2375 \\
\hline \multicolumn{6}{|l|}{ Mont Blanc (northern Alps) } \\
\hline Vallorcine La Poya & 1503 & $\mathrm{~S}$ & 1358 & 1577 & 1932 \\
\hline Saint-Nicolas-de-Véroce & 3657 & $\mathrm{M}$ & 1241 & 1751 & 2364 \\
\hline Les Houches - Saint-Gervais & 5872 & $\mathrm{~L}$ & 1068 & 1532 & 1892 \\
\hline Saint-Gervais Bettex & 7293 & $\mathrm{~L}$ & 1084 & 1549 & 2386 \\
\hline Contamines (Les)-Hauteluce & 10409 & $\mathrm{~L}$ & 1206 & 1786 & 2437 \\
\hline Megève & 15132 & XL & 1175 & 1557 & 2014 \\
\hline Chamonix & 27378 & XL & 1160 & 1938 & 3787 \\
\hline \multicolumn{6}{|l|}{ Bauges (northern Alps) } \\
\hline Seythenex - La Sambuy & 1170 & $\mathrm{~S}$ & 1160 & 1429 & 1835 \\
\hline Savoie Grand Revard & 1287 & $\mathrm{~S}$ & 1376 & 1339 & 1549 \\
\hline Semnoz (Le) & 1474 & $\mathrm{~S}$ & 1480 & 1505 & 1696 \\
\hline Aillon-le-Jeune-Margériaz & 3594 & $\mathrm{M}$ & 1029 & 1430 & 1834 \\
\hline
\end{tabular}


Table B1. Continued.

\begin{tabular}{|c|c|c|c|c|c|}
\hline & \multicolumn{5}{|c|}{ Resort features } \\
\hline & $\begin{array}{c}\text { Ski lift } \\
\text { power }\end{array}$ & $\begin{array}{l}\text { Size } \\
\text { category }\end{array}$ & $\begin{array}{l}\text { Village } \\
\text { elevation }\end{array}$ & $\begin{array}{r}\text { Mean } \\
\text { elevation }\end{array}$ & $\begin{array}{r}\text { Max. } \\
\text { elevation }\end{array}$ \\
\hline \multicolumn{6}{|l|}{ Beaufortain (northern Alps) } \\
\hline Granier-sur-Aime & 224 & $\mathrm{~S}$ & 1394 & 1522 & 1661 \\
\hline Crest-Voland & 3472 & M & 1257 & 1410 & 1608 \\
\hline Arêches-Beaufort & 4247 & M & 1104 & 1573 & 2137 \\
\hline Val d'Arly & 8345 & $\mathrm{~L}$ & 1158 & 1498 & 2053 \\
\hline Saisies (Les) & 8433 & $\mathrm{~L}$ & 1529 & 1727 & 2052 \\
\hline \multicolumn{6}{|l|}{ Haute-Tarentaise (northern Alps) } \\
\hline Sainte-Foy-Tarentaise & 2436 & $\mathrm{~S}$ & 1536 & 2067 & 2612 \\
\hline Rosière (la) & 6969 & $\mathrm{~L}$ & 1841 & 2031 & 2572 \\
\hline Val d'Isère & 24371 & XL & 1868 & 2368 & 3197 \\
\hline Tignes & 25814 & XL & 2092 & 2251 & 3459 \\
\hline Arcs (Les) - Peisey-Vallandry & 31699 & XL & 1786 & 1826 & 3220 \\
\hline \multicolumn{6}{|l|}{ Chartreuse (northern Alps) } \\
\hline Col de Marcieu & 221 & $S$ & 1070 & 1184 & 1350 \\
\hline Sappey-en-Chartreuse (Le) & 362 & $\mathrm{~S}$ & 988 & 1104 & 1344 \\
\hline Col de Porte & 372 & $\mathrm{~S}$ & 1329 & 1370 & 1615 \\
\hline Col du Granier - Désert d'Entremont (Le) & 506 & $\mathrm{~S}$ & 1106 & 1207 & 1428 \\
\hline Saint-Hilaire-du-Touvet & 517 & $\mathrm{~S}$ & 974 & 1075 & 1415 \\
\hline Saint-Pierre-de-Chartreuse - Le Planolet & 2958 & M & 982 & 1318 & 1751 \\
\hline \multicolumn{6}{|l|}{ Belledonne (northern Alps) } \\
\hline Col du Barioz Alpin & 190 & $S$ & 1366 & 1505 & 1684 \\
\hline Collet d'Allevard (Le) & 2897 & M & 1452 & 1715 & 2091 \\
\hline Chamrousse & 7078 & $\mathrm{~L}$ & 1732 & 1880 & 2253 \\
\hline Sept Laux (Les) & 10881 & $\mathrm{~L}$ & 1396 & 1786 & 2378 \\
\hline \multicolumn{6}{|l|}{ Maurienne (northern Alps) } \\
\hline Saint-Colomban-des-Villards & 1732 & $\mathrm{~S}$ & 1117 & 1586 & 2234 \\
\hline Albiez Montrond & 2708 & M & 1570 & 1725 & 2060 \\
\hline Karellis (Les) & 4986 & M & 1608 & 2043 & 2490 \\
\hline Toussuire (La) - Saint-Pancrace (Les Bottieres) & 6148 & $\mathrm{~L}$ & 1667 & 1939 & 2367 \\
\hline Corbier (Le)-Saint-Jean-d'Arves & 6363 & $\mathrm{~L}$ & 1555 & 1791 & 2377 \\
\hline Valmeinier & 7718 & $\mathrm{~L}$ & 1719 & 2017 & 2579 \\
\hline Valloire & 9631 & $\mathrm{~L}$ & 1482 & 1597 & 2530 \\
\hline \multicolumn{6}{|l|}{ Vanoise (northern Alps) } \\
\hline Notre-Dame-du-Pré & 226 & $\mathrm{~S}$ & 1279 & 1365 & 1510 \\
\hline Aussois & 3055 & M & 1535 & 2096 & 2670 \\
\hline Pralognan & 3505 & M & 1438 & 1495 & 2340 \\
\hline Orelle & 5217 & $\mathrm{~L}$ & 2364 & 2003 & 3242 \\
\hline Saint-François-Longchamp & 6405 & $\mathrm{~L}$ & 1583 & 1904 & 2514 \\
\hline Valmorel & 11005 & $\mathrm{~L}$ & 1382 & 1748 & 2401 \\
\hline Meribel Les Allues & 15767 & XL & 1362 & 1913 & 2701 \\
\hline Val Thorens & 19844 & XL & 2300 & 2501 & 3186 \\
\hline Menuires (Les) & 22331 & XL & 1798 & 2185 & 2845 \\
\hline Plagne (La) & 35044 & XL & 1849 & 2028 & 3167 \\
\hline Courchevel & 39787 & $\mathrm{XL}$ & 1667 & 2084 & 2919 \\
\hline
\end{tabular}


Table B1. Continued.

\begin{tabular}{|c|c|c|c|c|c|}
\hline & \multicolumn{5}{|c|}{ Resort features } \\
\hline & $\begin{array}{r}\text { Ski lift } \\
\text { power }\end{array}$ & $\begin{array}{l}\text { Size } \\
\text { category }\end{array}$ & $\begin{array}{l}\text { Village } \\
\text { elevation }\end{array}$ & $\begin{array}{r}\text { Mean } \\
\text { elevation }\end{array}$ & $\begin{array}{r}\text { Max. } \\
\text { elevation }\end{array}$ \\
\hline \multicolumn{6}{|c|}{ Haute-Maurienne (northern Alps) } \\
\hline Bramans & 16 & $\mathrm{~S}$ & 1261 & 1277 & 1315 \\
\hline Bessans & 185 & $\mathrm{~S}$ & 1715 & 1849 & 2079 \\
\hline Bonneval sur Arc & 2024 & $\mathrm{~S}$ & 1831 & 2339 & 2937 \\
\hline Valfréjus & 3773 & $\mathrm{M}$ & 1627 & 2086 & 2731 \\
\hline Norma (La) & 4032 & M & 1387 & 1964 & 2742 \\
\hline Val Cenis & 13212 & $\mathrm{~L}$ & 1440 & 1921 & 2737 \\
\hline \multicolumn{6}{|c|}{ Grandes-Rousses (northern Alps) } \\
\hline Chazelet-Villar d'Arene & 1088 & $\mathrm{~S}$ & 1664 & 1898 & 2164 \\
\hline Saint Sorlin d'Arves & 7746 & $\mathrm{~L}$ & 1556 & 2028 & 2590 \\
\hline $\mathrm{Oz}$ - Vaujany & 8072 & $\mathrm{~L}$ & 1311 & 1853 & 2817 \\
\hline Alpe d'Huez (l') & 18232 & $\mathrm{XL}$ & 1771 & 2125 & 3318 \\
\hline \multicolumn{6}{|l|}{ Vercors (northern Alps) } \\
\hline Saint-Nizier & 22 & $\mathrm{~S}$ & 1176 & 1181 & 1200 \\
\hline Rencurel & 221 & $\mathrm{~S}$ & 1081 & 1137 & 1233 \\
\hline Col de l'Arzelier & 472 & $\mathrm{~S}$ & 1171 & 1311 & 1477 \\
\hline Font d'Urle - Chaud Clapier & 504 & $\mathrm{~S}$ & 1433 & 1405 & 1542 \\
\hline Gresse-en-Vercors & 1257 & $\mathrm{~S}$ & 1251 & 1396 & 1703 \\
\hline Col de Rousset & 1297 & $\mathrm{~S}$ & 1275 & 1424 & 1695 \\
\hline Autrans & 1535 & $\mathrm{~S}$ & 1074 & 1415 & 1650 \\
\hline Méaudre & 1645 & $\mathrm{~S}$ & 1009 & 1265 & 1577 \\
\hline Lans en Vercors & 1880 & $\mathrm{~S}$ & 1137 & 1523 & 1801 \\
\hline Villard-de-Lans-Corrençon & 9644 & $\mathrm{~L}$ & 1221 & 1575 & 2052 \\
\hline \multicolumn{6}{|l|}{ Oisans (northern Alps) } \\
\hline Notre-Dame-de-Vaulx & 18 & $\mathrm{~S}$ & 972 & 1058 & 1085 \\
\hline Villard Reymond & 37 & $\mathrm{~S}$ & 1650 & 1691 & 1712 \\
\hline Motte d'Aveillans (La) & 84 & $\mathrm{~S}$ & 1285 & 1360 & 1430 \\
\hline Saint-Firmin-Valgaudemar & 91 & $\mathrm{~S}$ & 1306 & 1470 & 1580 \\
\hline Col d'Ornon & 401 & $\mathrm{~S}$ & 1366 & 1559 & 1855 \\
\hline Grave (La) & 995 & $\mathrm{~S}$ & 1498 & 2479 & 3532 \\
\hline Alpe du Grand Serre (l') & 3225 & M & 1403 & 1716 & 2221 \\
\hline Deux Alpes (Les) & 23796 & XL & 1720 & 2344 & 3642 \\
\hline \multicolumn{6}{|l|}{ Thabor (southern Alps) } \\
\hline Névache & 112 & $\mathrm{~S}$ & 1609 & 1643 & 1707 \\
\hline Montgenèvre & 8587 & $\mathrm{~L}$ & 1845 & 2143 & 2581 \\
\hline \multicolumn{6}{|l|}{ Pelvoux (southern Alps) } \\
\hline Pelvoux-Vallouise & 1391 & $\mathrm{~S}$ & 1398 & 1615 & 2237 \\
\hline Puy-Saint-Vincent & 5734 & $\mathrm{~L}$ & 1645 & 1938 & 2668 \\
\hline Serre Chevalier & 26571 & $\mathrm{XL}$ & 1376 & 1993 & 2750 \\
\hline \multicolumn{6}{|l|}{ Queyras (southern Alps) } \\
\hline Stations du Queyras & 6834 & $\mathrm{~L}$ & 1819 & 2024 & 2801 \\
\hline \multicolumn{6}{|l|}{ Dévoluy (southern Alps) } \\
\hline Lus la Jarjatte & 385 & $\mathrm{~S}$ & 1171 & 1339 & 1521 \\
\hline Massif du Dévoluy & 7068 & $\mathrm{~L}$ & 1506 & 1591 & 2490 \\
\hline
\end{tabular}


Table B1. Continued.

\begin{tabular}{|c|c|c|c|c|c|}
\hline & \multicolumn{5}{|c|}{ Resort features } \\
\hline & $\begin{array}{l}\text { Ski lift } \\
\text { power }\end{array}$ & $\begin{array}{l}\text { Size } \\
\text { category }\end{array}$ & $\begin{array}{l}\text { Village } \\
\text { elevation }\end{array}$ & $\begin{array}{r}\text { Mean } \\
\text { elevation }\end{array}$ & $\begin{array}{r}\text { Max. } \\
\text { elevation }\end{array}$ \\
\hline \multicolumn{6}{|l|}{ Champsaur (southern Alps) } \\
\hline Ancelle & 1842 & $\mathrm{~S}$ & 1351 & 1511 & 1811 \\
\hline Stations Village du Champsaur & 3907 & $\mathrm{M}$ & 1386 & 1486 & 2240 \\
\hline Orcières Merlette & 8297 & $\mathrm{~L}$ & 1836 & 2178 & 2725 \\
\hline \multicolumn{6}{|l|}{ Embrunnais Parpaillon (southern Alps) } \\
\hline Réallon & 1408 & $\mathrm{~S}$ & 1569 & 1789 & 2114 \\
\hline Orres (Les) & 6545 & $\mathrm{~L}$ & 1687 & 2027 & 2704 \\
\hline Risoul & 6734 & $\mathrm{~L}$ & 1900 & 2188 & 2551 \\
\hline \multicolumn{6}{|l|}{ Ubaye (southern Alps) } \\
\hline Col Saint Jean & 2952 & M & 1345 & 1883 & 2450 \\
\hline Stations de l'Ubaye & 5825 & $\mathrm{~L}$ & 1523 & 1909 & 2427 \\
\hline Pra Loup & 6772 & $\mathrm{~L}$ & 1621 & 1904 & 2500 \\
\hline Vars & 9073 & $\mathrm{~L}$ & 1832 & 2079 & 2721 \\
\hline \multicolumn{6}{|l|}{ Haut-Var Haut-Verdon (southern Alps) } \\
\hline Val Pelens & 169 & $\mathrm{~S}$ & 1612 & 1662 & 1737 \\
\hline Roubion les Buisses & 728 & $\mathrm{~S}$ & 1443 & 1611 & 1898 \\
\hline Valberg-Beuil & 4849 & $\mathrm{M}$ & 1665 & 1650 & 2020 \\
\hline Val d'Allos & 8257 & $\mathrm{~L}$ & 1730 & 1580 & 2500 \\
\hline \multicolumn{6}{|l|}{ Mercantour (southern Alps) } \\
\hline Stations du Mercantour & 17669 & $\mathrm{XL}$ & 1784 & 2029 & 2585 \\
\hline \multicolumn{6}{|l|}{ Aspe Ossau (French Pyrenees) } \\
\hline Artouste & 2565 & M & 1894 & 1730 & 2040 \\
\hline Gourette - Pierre Saint Martin (La) & 8788 & $\mathrm{~L}$ & 1420 & 1543 & 2453 \\
\hline \multicolumn{6}{|l|}{ Haute-Bigorre (French Pyrenees) } \\
\hline Val d'Azun & 14 & $\mathrm{~S}$ & 1469 & 1469 & 1469 \\
\hline Pic du Midi & 516 & $\mathrm{~S}$ & 1780 & 2292 & 2856 \\
\hline Hautacam & 919 & $\mathrm{~S}$ & 1520 & 1454 & 1729 \\
\hline Gavarnie & 1999 & $\mathrm{~S}$ & 1846 & 1997 & 2282 \\
\hline Piau Engaly & 3819 & $\mathrm{M}$ & 1841 & 2030 & 2529 \\
\hline Luz Ardiden & 4099 & $\mathrm{M}$ & 1716 & 1951 & 2484 \\
\hline Cauterets & 7193 & $\mathrm{~L}$ & 1755 & 1932 & 2416 \\
\hline Tourmalet & 10243 & $\mathrm{~L}$ & 1784 & 1866 & 2490 \\
\hline Saint Lary Soulan & 12822 & $\mathrm{~L}$ & 1653 & 1991 & 2471 \\
\hline \multicolumn{6}{|l|}{ Aure Louron (French Pyrenees) } \\
\hline Val Louron & 1693 & $\mathrm{~S}$ & 1462 & 1723 & 2058 \\
\hline Peyragudes & 7741 & $\mathrm{~L}$ & 1623 & 1884 & 2260 \\
\hline \multicolumn{6}{|l|}{ Luchonnais (French Pyrenees) } \\
\hline Bourg d'Oueil & 109 & $\mathrm{~S}$ & 1345 & 1438 & 1498 \\
\hline Superbagnères & 6446 & $\mathrm{~L}$ & 1792 & 1736 & 2133 \\
\hline \multicolumn{6}{|l|}{ Couserans (French Pyrenees) } \\
\hline Le Mourtis & 1096 & $\mathrm{~S}$ & 1425 & 1578 & 1801 \\
\hline Guzet Neige & 2673 & M & 1445 & 1600 & 2050 \\
\hline \multicolumn{6}{|l|}{ Haute-Ariege (French Pyrenees) } \\
\hline Ax Les Thermes & 7437 & $\mathrm{~L}$ & 1398 & 1955 & 2948 \\
\hline
\end{tabular}


Table B1. Continued.

\begin{tabular}{|c|c|c|c|c|c|}
\hline & \multicolumn{5}{|c|}{ Resort features } \\
\hline & $\begin{array}{r}\text { Ski lift } \\
\text { power }\end{array}$ & $\begin{array}{l}\text { Size } \\
\text { category }\end{array}$ & $\begin{array}{l}\text { Village } \\
\text { elevation }\end{array}$ & $\begin{array}{r}\text { Mean } \\
\text { elevation }\end{array}$ & $\begin{array}{r}\text { Max. } \\
\text { elevation }\end{array}$ \\
\hline \multicolumn{6}{|l|}{ Orlu St-Barthélémy (French Pyrenees) } \\
\hline Camurac & 527 & $\mathrm{~S}$ & 1417 & 1335 & 1755 \\
\hline Ascou & 820 & $\mathrm{~S}$ & 1558 & 1731 & 2058 \\
\hline Mijane - Goulier - Plateau de Beille & 891 & $\mathrm{~S}$ & 1663 & 1599 & 2013 \\
\hline Monts d'Olmes & 1922 & $\mathrm{~S}$ & 1487 & 1647 & 1948 \\
\hline \multicolumn{6}{|l|}{ Capcir Puymorens (French Pyrenees) } \\
\hline Quillane (La) & 111 & $\mathrm{~S}$ & 1709 & 1752 & 1812 \\
\hline Porté-Puymorens & 1800 & $\mathrm{~S}$ & 1755 & 1259 & 2342 \\
\hline Formiguères & 1869 & $\mathrm{~S}$ & 1769 & 1974 & 2320 \\
\hline Font Romeu - P2000 & 5132 & $\mathrm{~L}$ & 1775 & 1982 & 2227 \\
\hline Angles (Les) & 5478 & $\mathrm{~L}$ & 1683 & 1968 & 2361 \\
\hline \multicolumn{6}{|l|}{ Cerdagne Canigou (French Pyrenees) } \\
\hline Cambre d'Aze & 1741 & $\mathrm{~S}$ & 1745 & 1958 & 2424 \\
\hline \multicolumn{6}{|c|}{ Andorra (Spanish and Andorran Pyrenees) } \\
\hline Arinsal & 1663 & $\mathrm{~S}$ & 1706 & 2147 & 2531 \\
\hline Pal & 3054 & M & 1651 & 2062 & 2351 \\
\hline Ordino-Arcalis & 3897 & M & 1792 & 2281 & 2633 \\
\hline Grandvalira & 19747 & XL & 1772 & 2251 & 2669 \\
\hline \multicolumn{6}{|c|}{ Jacetania (Spanish and Andorran Pyrenees) } \\
\hline Astún & 3304 & M & 1591 & 1968 & 2249 \\
\hline Candanchú & 4573 & M & 1506 & 1836 & 2283 \\
\hline Formigal & 11251 & $\mathrm{~L}$ & 1562 & 1923 & 2263 \\
\hline \multicolumn{6}{|c|}{ Gallego (Spanish and Andorran Pyrenees) } \\
\hline Panticosa & 2799 & $\mathrm{M}$ & 1476 & 1789 & 2191 \\
\hline \multicolumn{6}{|l|}{ Esera (Spanish and Andorran Pyrenees) } \\
\hline Cerler & 7000 & $\mathrm{~L}$ & 1694 & 2129 & 2645 \\
\hline \multicolumn{6}{|l|}{ Aran (Spanish and Andorran Pyrenees) } \\
\hline Baqueira Beret & 21246 & $\mathrm{XL}$ & 1685 & 2115 & 2543 \\
\hline \multicolumn{6}{|c|}{ Ribagorçana (Spanish and Andorran Pyrenees) } \\
\hline Boí Taüll & 4648 & M & 1825 & 2333 & 2741 \\
\hline \multicolumn{6}{|c|}{ Pallaresa (Spanish and Andorran Pyrenees) } \\
\hline Espot & 2554 & M & 1609 & 1997 & 2339 \\
\hline Port Ainé & 2927 & M & 1714 & 2160 & 2432 \\
\hline Tavascan & 774 & $\mathrm{~S}$ & 1582 & 1954 & 2220 \\
\hline \multicolumn{6}{|c|}{ Ter-Freser (Spanish and Andorran Pyrenees) } \\
\hline Vall de Núria & 1040 & $\mathrm{~S}$ & 1656 & 2070 & 2303 \\
\hline Vallter 2000 & 2036 & $\mathrm{~S}$ & 1797 & 2289 & 2526 \\
\hline \multicolumn{6}{|c|}{ Cadi Moixero (Spanish and Andorran Pyrenees) } \\
\hline La Molina & 14282 & $\mathrm{~L}$ & 1603 & 1988 & 2527 \\
\hline \multicolumn{6}{|c|}{ Pre-Pyrenees (Spanish and Andorran Pyrenees) } \\
\hline Port del Comte & 5301 & $\mathrm{~L}$ & 1624 & 2020 & 2329 \\
\hline
\end{tabular}


Author contributions. SM and EG designed the research; PS developed the model, carried out the experiments, and produced the data and most figures with support from co-authors; HF contributed to produce the data and mapping figures; DV produced the adjusted climate projections; ML contributed to the development of the model and production of climate forcing data; MV contributed to the production of the reanalysis forcing data; MP provided input for the Spanish and Andorran resorts; all authors contributed to the analysis and interpretation of the results; PS wrote the paper, based on input and feedback from all co-authors.

Competing interests. The authors declare that they have no conflict of interest.

Acknowledgements. This study was funded by Région RhôneAlpes ( $\mathrm{PhD}$ grant of Pierre Spandre), and benefited from funding from the French Ministry for Ecology (MTES) to the ADAMONT project through GICC and ONERC, from the Interreg project POCTEFA/Clim'Py (OPCC2), from the IDEX Univ. Grenoble Alpes Cross Disciplinary Project "Trajectories", and from the Conseil Départemental de l'Isère - Isère Tourisme. The CGET - Comité de Massif Alpes funded the creation of the BD Stations database. CNRM/CEN and Irstea are part of LabEX OSUG@2020 (ANR10 LABX56). Deborah Verfaillie's work has been funded by the European project EUCP (H2020-SC5-2016776613). We acknowledge useful comments and suggestions from O. Cenk Demiroglu, Robert Steiger, one anonymous reviewer and the editor Jürg Schweizer.

Review statement. This paper was edited by Jürg Schweizer and reviewed by Cenk Demiroglu, Robert Steiger, and one anonymous referee.

\section{References}

Abegg, B., Agrawala, S., Crick, F., and de Montfalcon, A.: Climate change impacts and adaptation in winter tourism, in: Climate Change in the European Alps, edited by: Agrawala, S., OECD Paris, 25-60, https://doi.org/10.1787/9789264031692-en, 2007.

Beniston, M., Farinotti, D., Stoffel, M., Andreassen, L. M., Coppola, E., Eckert, N., Fantini, A., Giacona, F., Hauck, C., Huss, M., Huwald, H., Lehning, M., López-Moreno, J.-I., Magnusson, J., Marty, C., Morán-Tejéda, E., Morin, S., Naaim, M., Provenzale, A., Rabatel, A., Six, D., Stötter, J., Strasser, U., Terzago, S., and Vincent, C.: The European mountain cryosphere: a review of its current state, trends, and future challenges, The Cryosphere, 12, 759-794, https://doi.org/10.5194/tc-12-759-2018, 2018.

Breiling, M. and Charamza, P.: The impact of global warming on winter tourism and skiing: a regionalised model for Austrian snow conditions, Reg. Environ. Change, 1, 4-14, https://doi.org/10.1007/s101130050003, 1999.

Brun, E., David, P., Sudul, M., and Brunot, G.: A numerical model to simulate snow-cover stratigraphy for operational avalanche forecasting, J. Glaciol., 38, 13-22, 1992.
Damm, A., Greuell, W., Landgren, O., and Prettenthaler, F.: Impacts of $+2{ }^{\circ} \mathrm{C}$ global warming on winter tourism demand in Europe, Climate Services, 7, 31-46, https://doi.org/10.1016/j.cliser.2016.07.003, 2017.

Dawson, J. and Scott, D.: Managing for climate change in the alpine ski sector, Tourism Manage., 35, 244-254, https://doi.org/10.1016/j.tourman.2012.07.009, 2013.

Durand, Y., Brun, E., Mérindol, L., Guyomarc'h, G., Lesaffre, B., and Martin, E.: A meteorological estimation of relevant parameters for snow models, Ann. Glaciol., 18, 65-71, 1993.

Durand, Y., Giraud, G., Laternser, M., Etchevers, P., Mérindol, L., and Lesaffre, B.: Reanalysis of 47 Years of Climate in the French Alps (1958-2005): Climatology and Trends for Snow Cover, J. Appl. Meteorol. Clim., 48, 2487-2512, https://doi.org/10.1175/2009JAMC1810.1, 2009a.

Durand, Y., Giraud, G., Laternser, M., Etchevers, P., Mérindol, L., and Lesaffre, B.: Reanalysis of $44 \mathrm{Yr}$ of Climate in the French Alps (1958-2002): Methodology, Model Validation, Climatology, and Trends for Air Temperature and Precipitation., J. Appl. Meteorol. Clim., 48, 429-449, https://doi.org/10.1175/2008JAMC1808.1, 2009 b.

Durand, Y., Giraud, G., Goetz, D., Maris, M., and Payen, V.: Modeled Snow Cover in Pyrenees Mountains and Cross-Comparisons Between Remote-Sensed and Land-Based Observation Data, in: Proceedings of the International Snow Science Workshop, 1621 September 2012, Anchorage, Alaska, USA, vol. 9981004 , 2012.

Elsasser, H. and Bürki, R.: Climate change as a threat to tourism in the Alps, Clim. Res., 20, 253-257, https://doi.org/10.3354/cr020253, 2002.

Falk, M. and Vanat, L.: Gains from investments in snowmaking facilities, Ecol. Econ., 130, 339-349, https://doi.org/10.1016/j.ecolecon.2016.08.003, 2016.

François, H., Morin, S., Lafaysse, M., and George-Marcelpoil, E.: Crossing numerical simulations of snow conditions with a spatially-resolved socio-economic database of ski resorts: A proof of concept in the French Alps, Cold Reg. Sci. Technol., 108, 98-112, https://doi.org/10.1016/j.coldregions.2014.08.005, 2014.

Gilaberte-Burdalo, M., Lopez-Martin, F., M. R. PinoOtin, M., and Lopez-Moreno, J.: Impacts of climate change on ski industry, Environ. Sci. Pol., 44, 51-61, https://doi.org/10.1016/j.envsci.2014.07.003, 2014.

Gilaberte-Búrdalo, M., López-Moreno, J., Morán-Tejeda, E., Jerez, S., Alonso-González, E., López-Martín, F., and Pino-Otín, M.: Assessment of ski condition reliability in the Spanish and Andorran Pyrenees for the second half of the 20th century, Appl. Geogr., 79, 127-142, https://doi.org/10.1016/j.apgeog.2016.12.013, 2017.

Hanzer, F., Marke, T., and Strasser, U.: Distributed, explicit modeling of technical snow production for a ski area in the Schladming region (Austrian Alps), Cold Reg. Sci. Technol., 108, 113-124, https://doi.org/10.1016/j.coldregions.2014.08.003, 2014.

Hendrikx, J. and Hreinsson, E.: The potential impact of climate change on seasonal snow in New Zealand: industry vulnerability and future snowmaking potential, Theor. Appl. Climatol., 110, 619-630, https://doi.org/10.1007/s00704-012-0713-z, 2012.

Hennessy, K., Whetton, P., Walsh, K., Smith, I., Bathols, J., Hutchinson, M., and Sharples, J.: Climate change effects 
on snow conditions in mainland Australia and adaptation at ski resorts through snowmaking, Clim. Res., 35, 255, https://doi.org/10.3354/cr00706, 2007.

Hoegh-Guldberg, O., Jacob, D., Taylor, M., Bindi, M., Brown, S., Camilloni, I., Diedhiou, A., Djalante, R., Ebi, K., Engelbrecht, F., Guiot, J., Hijioka, Y., Mehrotra, S., Payne, A., Seneviratne, S., Thomas, A., Warren, R., and Zhou, G.: Impacts of $1.5^{\circ} \mathrm{C}$ Global Warming on Natural and Human Systems, in: Global Warming of $1.5^{\circ} \mathrm{C}$. An IPCC Special Report on the impacts of global warming of $1.5^{\circ} \mathrm{C}$ above pre-industrial levels and related global greenhouse gas emission pathways, in the context of strengthening the global response to the threat of climate change, sustainable development, and efforts to eradicate poverty, edited by: Masson-Delmotte, V., Zhai, P., Portner, H.-O., Roberts, D., Skea, J., Shukla, P. R., Pirani, A., Moufouma-Okia, W., Pean, C., Pidcock, R., Connors, S., Matthews, J. B. R., Chen, Y., Zhou, X., Gomis, M. I., Lonnoy, E., Maycock, T., Tignor, M., and Waterfield, T., in press, 2019.

Jacob, D., Petersen, J., Eggert, B., Alias, A., Christensen, O. B., Bouwer, L. M., Braun, A., Colette, A., Deque, M., Georgievski, G., Georgopoulou, E., Gobiets, A., Menut, L., Nikulin, G., Haensler, A., Hempelmann, N., Jones, C., Keuler, K., Kovats, S., Kroner, N., Kotlarski, S., Kriegsmann, A., Martin, E., Meijgaard, E. V., Moseley, C., Pfeifer, S., Preuschmann, S., Radermacher, C., Radtke, K., Rechid, D., Rounsevell, M., Samuelsson, P., Somot, S., Soussana, J.-F., Teichmann, C., Valentini, R., Vautard, R., Weber, B., and Yiou, P.: EUROCORDEX: new high-resolution climate change projections for European impact research, Reg. Environ. Change, 14, 563-578, https://doi.org/10.1007/s10113-013-0499-2, 2014.

Koenig, U. and Abegg, B.: Impacts of climate change on winter tourism in the Swiss Alps, J. Sustain. Tour., 5, 46-58, https://doi.org/10.1080/09669589708667275, 1997.

Kotlarski, S., Keuler, K., Christensen, O. B., Colette, A., Déqué, M., Gobiet, A., Goergen, K., Jacob, D., Lüthi, D., van Meijgaard, E., Nikulin, G., Schär, C., Teichmann, C., Vautard, R., Warrach-Sagi, K., and Wulfmeyer, V.: Regional climate modeling on European scales: a joint standard evaluation of the EUROCORDEX RCM ensemble, Geosci. Model Dev., 7, 1297-1333, https://doi.org/10.5194/gmd-7-1297-2014, 2014.

Laternser, M. and Schneebeli, M.: Long-term snow climate trends of the Swiss Alps (1931-99), Int. J. Climatol., 23, 733-750, https://doi.org/10.1002/joc.912, 2003.

Luthe, T., Wyss, R., and Schuckert, M.: Network governance and regional resilience to climate change: empirical evidence from mountain tourism communities in the Swiss Gotthard region, Reg. Environ. Change, 12, 839-854, https://doi.org/10.1007/s10113-012-0294-5, 2012.

Maris, M., Giraud, G., Durand, Y., Navarre, J.-P., and Mérindol, L.: Results of 50 years of climate reanalysis in the French Pyrenees (1958-2008) using the SAFRAN and CROCUS models, in: Proceedings of the International Snow Science Workshop, 27 September-2 October 2009, Davos, Switzerland, 219-223, 2009.

Marke, T., Strasser, U., Hanzer, F., Stötter, J., Wilcke, R., and Gobiet, A.: Scenarios of future snow conditions in Styria (Austrian Alps), J. Hydrometeorol., 16, 261-277, https://doi.org/10.1175/JHM-D-14-0035.1, 2014.
Matulla, C., Auer, I., Böhm, R., Ungersböck, M., Schöner, W., Wagner, S., and Zorita, E.: Outstanding past decadal-scale climate events in the Greater Alpine Region analysed by 250 years data and model runs, GKSS-Forschungszentrum, Geesthacht, Germany, 2005.

Morin, S., Abegg, B., Demiroglu, O. C., Pons, M., Weber, F., Amacher, A., François, H., George, E., Soubeyroux, J. M., Samacoits, R., Lafaysse, M., Franklin, S., Clifford, D., Cauchy, A., and Dubois, G.: The "Mountain Tourism" component of the Copernicus Climate Change Services - Sectoral Information Service "European Tourism": towards pan-European analysis and projections of natural and managed snow conditions, in: Proceedings of the International Snow Science Workshop, 7-12 October 2018, Innsbruck, Austria, 542-547, 2018.

Moss, R., Edmonds, J., Hibbard, K., Manning, M., Rose, S., Van Vuuren, D., Carter, T., Emori, S., Kainuma, M., Kram, T., Meehl, G. A., Mitchell, J. F. B., Nakicenovic, N., Riahi, K., Smith, S. J., Stouffer, R. J., Thomson, A. M., Weyant, J. P., and Wilbanks, T. J.: The next generation of scenarios for climate change research and assessment, Nature, 463, 747-756, https://doi.org/10.1038/nature08823, 2010.

Mott, R., Daniels, M., and Lehning, M.: Atmospheric Flow Development and Associated Changes in Turbulent Sensible Heat Flux over a Patchy Mountain Snow Cover, J. Hydrometeorol., 16, 1315-1340, https://doi.org/10.1175/JHM-D-14-0036.1, 2015.

Pons, M., López-Moreno, J., Rosas-Casals, M., and Jover, E.: The vulnerability of Pyrenean ski resorts to climate-induced changes in the snowpack, Climatic Change, 131, 591-605, https://doi.org/10.1007/s10584-015-1400-8, 2015.

Pons-Pons, M., Johnson, P. A., Rosas Casals, M., Sureda Carbonell, B., and Jover Comas, E.: Modeling climate change effects on winter ski tourism in Andorra, Clim. Res., 54, 197-207, https://doi.org/10.3354/cr01117, 2012.

Rixen, C., Teich, M., Lardelli, C., Gallati, D., Pohl, M., Pütz, M., and Bebi, P.: Winter tourism and climate change in the Alps: an assessment of resource consumption, snow reliability, and future snowmaking potential, Mt. Res. Dev., 31, 229-236, https://doi.org/10.1659/MRD-JOURNAL-D-10-00112.1, 2011.

Schmidt, P., Steiger, R., and Matzarakis, A.: Artificial snowmaking possibilities and climate change based on regional climate modeling in the Southern Black Forest, Meteorol. Z., 21, 167-172, https://doi.org/10.1127/0941-2948/2012/0281, 2012.

Scott, D., McBoyle, G., and Mills, B.: Climate change and the skiing industry in Southern Ontario (Canada): exploring the importance of snowmaking as a technical adaptation, Clim. Res., 23, 171-181, https://doi.org/10.3354/cr023171, 2003.

Scott, D., McBoyle, G., Minogue, A., and Mills, B.: Climate change and the sustainability of ski-based tourism in eastern North America: A reassessment, J. Sustain. Tour., 14, 376-398, https://doi.org/10.2167/jost550.0, 2006.

Spandre, P., François, H., Morin, S., and George-Marcelpoil, E.: Snowmaking in the French Alps. Climatic context, existing facilities and outlook, Rev. Geogr. Alp., 103-2, https://doi.org/10.4000/rga.2913, 2015.

Spandre, P., François, H., George-Marcelpoil, E., and Morin, S.: Panel based assessment of snow management operations in French ski resorts, Journal of Outdoor Recreation and Tourism, 16, 24-36, https://doi.org/10.1016/j.jort.2016.09.002, 2016 a. 
Spandre, P., Morin, S., Lafaysse, M., George-Marcelpoil, E., François, H., and Lejeune, Y.: Integration of snow management in a detailed snowpack model, Cold Reg. Sci. Technol., 125, 4864, https://doi.org/10.1016/j.coldregions.2016.01.002, $2016 \mathrm{~b}$.

Spandre, P., François, Verfaillie, D., Lafaysse, M., Déqué, M., Eckert, N., George, E., and Morin, S.: Climate change impacts on the snow reliability of French Alps ski resorts, in: Proceedings of the International Snow Science Workshop, 7-12 October 2018, Innsbruck, Austria, 512-516, 2018.

Steiger, R.: The impact of climate change on ski season length and snowmaking requirements in Tyrol, Austria, Clim. Res., 43, 251262, https://doi.org/10.3354/cr00941, 2010.

Steiger, R. and Mayer, M.: Snowmaking and climate change: Future options for snow production in Tyrolean ski resorts, Mt. Res. Dev., 28, 292-298, https://doi.org/10.1659/mrd.0978, 2008.

Steiger, R., Scott, D., Abegg, B., Pons, M., and Aall, C.: A critical review of climate change risk for ski tourism, Curr. Issues Tour., 1-37, https://doi.org/10.1080/13683500.2017.1410110, 2017.

Taylor, K., Stouffer, R., and Meehl, G.: An overview of CMIP5 and the experiment design, B. Am. Meteorol. Soc., 93, 485-498, https://doi.org/10.1175/BAMS-D-11-00094.1, 2012.
Verfaillie, D., Déqué, M., Morin, S., and Lafaysse, M.: The method ADAMONT v1.0 for statistical adjustment of climate projections applicable to energy balance land surface models, Geosci. Model Dev., 10, 4257-4283, https://doi.org/10.5194/gmd-104257-2017, 2017.

Verfaillie, D., Lafaysse, M., Déqué, M., Eckert, N., Lejeune, Y., and Morin, S.: Multi-component ensembles of future meteorological and natural snow conditions for $1500 \mathrm{~m}$ altitude in the Chartreuse mountain range, Northern French Alps, The Cryosphere, 12, 1249-1271, https://doi.org/10.5194/tc-12-1249-2018, 2018.

Vionnet, V., Brun, E., Morin, S., Boone, A., Faroux, S., Le Moigne, P., Martin, E., and Willemet, J.-M.: The detailed snowpack scheme Crocus and its implementation in SURFEX v7.2, Geosci. Model Dev., 5, 773-791, https://doi.org/10.5194/gmd-5773-2012, 2012.

Wielke, L. M., Haimberger, L., and Hantel, M.: Snow cover duration in Switzerland compared to Austria, Meteorol. Z., 13, 1317, https://doi.org/10.1127/0941-2948/2004/0013-0013, 2004. 